\title{
Potential climatic influence on maximum stand carrying capacity for 15 Mediterranean coniferous and broadleaf species
}

\author{
Diego Rodríguez de Prado ${ }^{\mathrm{a}, \mathrm{b}, *}$, Roberto San Martín ${ }^{\mathrm{b}}$, Felipe Bravo ${ }^{\mathrm{b}}$, Celia Herrero de Aza ${ }^{\mathrm{a}, \mathrm{b}}$ \\ ${ }^{a}$ ECM Ingeniería Ambiental, S.L. C/Curtidores 17, Palencia 34003, Spain \\ ${ }^{\mathrm{b}}$ Instituto Universitario de Investigación en Gestión Forestal Sostenible (iUFOR), Universidad de Valladolid-INIA. Avda, Madrid 44, Palencia 34004, Spain
}

\section{A R T I C L E I N F O}

\section{Keywords:}

Self-thinning

Reineke

Maximum Stand Density Index

Forest Management

National Forest Inventory Data

\begin{abstract}
A B S T R A C T
Climate change projections for the Mediterranean basin predict a continuous increase in extreme drought and heat episodes, which will affect forest dynamics, structure and composition. Understanding how climate influences the maximum size-density relationship (MSDR) is therefore critical to designing adaptive silvicultural guidelines based on the potential stand carrying capacity of tree species. With this aim, data from the Third Spanish National Forest Inventory (3NFI) and WorldClim databases were used to analyze climate-related variations of the maximum stand carrying capacity for 15 species from the Pinus, Fagus and Quercus genera. First, basic MSDR were fitted using linear quantile regression and observed size-density data from monospecific 3NFI plots. Reference values for maximum stocking, expressed in terms of the Maximum Stand Density Index (SDI max $_{\text {), }}$ were estimated by species. Then, climate-dependent MSDR models including 35 annual and seasonal climatic variables were fitted. The best climate-dependent models, based on the Akaike Information Criteria (AIC) index, were used to determine the climatic drivers affecting MSDR, to analyze general and species-specific patterns and to quantify the impact of climate on maximum stand carrying capacity. The results showed that all the selected climate-dependent models improved the goodness of fit over the basic models. Among the climatic variables, spring and summer maximum temperatures were found to be key drivers affecting MSDR for the species studied. A common trend was also found across species, linking warmer and drier conditions to smaller $\mathrm{SDI}_{\max } \mathrm{values}$ Based on projected climate scenarios, this suggests potential reductions in maximum stocking for these species. In this study, a new index was proposed, the $Q$ index, for evaluating the impact of climate on maximum stand carrying capacity. Our findings highlight the importance of using specific climatic variables to better characterize how they affect MSDR. The models presented in this study will allow us to better explain interactions between climate and MSDR while also providing more precise estimates concerning maximum stocking for different Mediterranean coniferous and broadleaf tree species.
\end{abstract}

\section{Introduction}

Maximum stand carrying capacity is a key variable in forest management and commonly used to develop site resources for sustainable, healthy and optimal stand growth. Reineke (1933) was the first to address this concept when he proposed the Maximum Stand Density Index $\left(\mathrm{SDI}_{\max }\right)$, an attribute that determines full site occupancy (Zeide, 2005). He discovered that for any given tree size (i.e. $25 \mathrm{~cm}$ ), the physiological attributes of a species constrain the maximum number of trees that a fully stocked stand can support before natural mortality takes place. This relationship is widely recognized in forest science (Reineke, 1933; Drew and Flewelling, 1977) and ecology (Yoda et al., 1963; Fowler, 1981) as the Maximum Size-Density Relationship (MSDR). Also known as the self-thinning line, its applications encompass studies related to habitat distribution (Moore and Deiter, 1992), risk assessment due to abiotic and biotic factors (Fettig et al., 2007; Ducey et al., 2017) or the carbon sink capacity of forests (Woodall et al., 2011; Brunet-Navarro et al., 2016). Its use also extends to the development of forest management tools such as forest growth models (Makela et al., 2000; Yang and Titus, 2002), density management diagrams (Long and Shaw, 2005; Valbuena et al., 2008) and forest management plans (Jack and Long, 1996; Churchill et al., 2013). Initially, Reineke (1933) and Yoda et al. (1963) claimed that the MSDR, and therefore the maximum stand carrying capacity, might not be influenced by environmental conditions or site quality. However, recent studies show that this relationship varies with site quality (Bi, 2001; Comeau et al., 2010), stand origin (Weiskittel et al., 2009), nutrient availability (Morris, 2003; ReyesHernandez et al., 2013) and stand age (Zeide, 2005). The influence of

\footnotetext{
* Corresponding author.

E-mail address: rdprado@ecmingenieriaambiental.com (D. Rodríguez de Prado).
} 
climate on MSDR deserves special attention, since it is widely accepted that climate is changing. Forest stands are already experiencing alterations in composition, structure and dynamics (IPCC, 2018). Relevant projections suggest that climate change will continue to affect site conditions, including stand carrying capacity, species distribution and niche suitability. Recent studies confirm that the size-density relationship is affected by climate, indicating an important decline in maximum stand carrying capacity associated with potential drought conditions in different areas of the Mediterranean basin (Condés et al., 2017; Aguirre et al., 2018). These studies frequently use annual climatic variables, such as the De Martonne Index (1926), to study climatic influences on MSDR. However, studies involving more precise (monthly or seasonal) climatic variables are needed to better understand this relationship. Kweon and Comeau (2017), for example, used periodic climatic variables such us degree-days above $5{ }^{\circ} \mathrm{C}$, degree-days below $0{ }^{\circ} \mathrm{C}$ or summer heat moisture index (the ratio between mean warmest month temperature and mean summer precipitation) to better characterize environmental conditions. They found that higher temperatures and longer frost-free periods could negatively affect the maximum stand carrying capacity. The effect of climate on MSDR has also been widely studied in mixed stands (Condés et al., 2013; del Río et al., 2014; Pretzsch and Biber, 2016; Andrews et al., 2018). Recent research has focused more on estimating size-density relationships for coniferous species (Brunet-Navarro et al., 2016; Aguirre et al., 2018), but less has been done in relation to broadleaf species. Future work should focus on discovering potential changes in the structure, composition and dynamics of monospecific broadleaf and mixed conifer-broadleaf stands. Species composition and functional traits have also been indicated as key drivers affecting the maximum stand carrying capacity (Ducey et al., 2017; Kimsey et al., 2019). All these works highlight the importance of considering a range of environmental conditions, to better understand regional landscape patterns that can inform the estimation of maximum stocking. To that end, National Forest Inventory (NFI) data has proven a suitable database for studying climatic influences on MSDRs, as it covers a wide variety of forest types, stand structures and species distributed along a gradient of environmental conditions (Condés et al., 2017; Andrews et al., 2018; Toigo et al., 2018). Previous studies have used NFI data and diverse statistical methods to fit basic and climate-dependent MSDR models (Zhang et al., 2005; Hann, 2014). Principal component analysis (Hutchings and Budd, 1981; Weller, 1987; Bégin et al., 2001), stochastic frontier analysis (Bi et al., 2000; Bi, 2004; Charru et al., 2012) and linear quantile regression (Zhang et al., 2013; Vospernik and Sterba, 2015) are the methods most commonly used to fit the self-thinning line. The linear quantile regression method was chosen for the study presented here, as it can provide statistical analysis and estimates for fitting linear models to either the conditional median or other quantiles of the response variable, without stringent assumptions on the error distribution (Koenker and Bassett, 1978). Exploring the relationship between climate and the maximum carrying capacity of a forest stand is therefore key to understanding the dynamics that can inform sustainable use and management of the products and services it provides. Accordingly, the main objective of this work was to study the influence of climate on the maximum stand carrying capacity (expressed as SDI $_{\max }$ ) of 15 coniferous and broadleaf species in Spain (Table 1). The specific objectives of the study were: (i) to fit new basic and climate-dependent MSDR models and discover the key climatic drivers influencing MSDR by species, (ii) to estimate the maximum stand carrying capacity for these species with and without climate influence, and (iii) to analyze and quantify general and speciesspecific trends in $\mathrm{SDI}_{\max }$ variation for the species studied.

\section{Material and methods}

\subsection{Data}

Spanish Third National Forest Inventory (3NFI) plots were used for

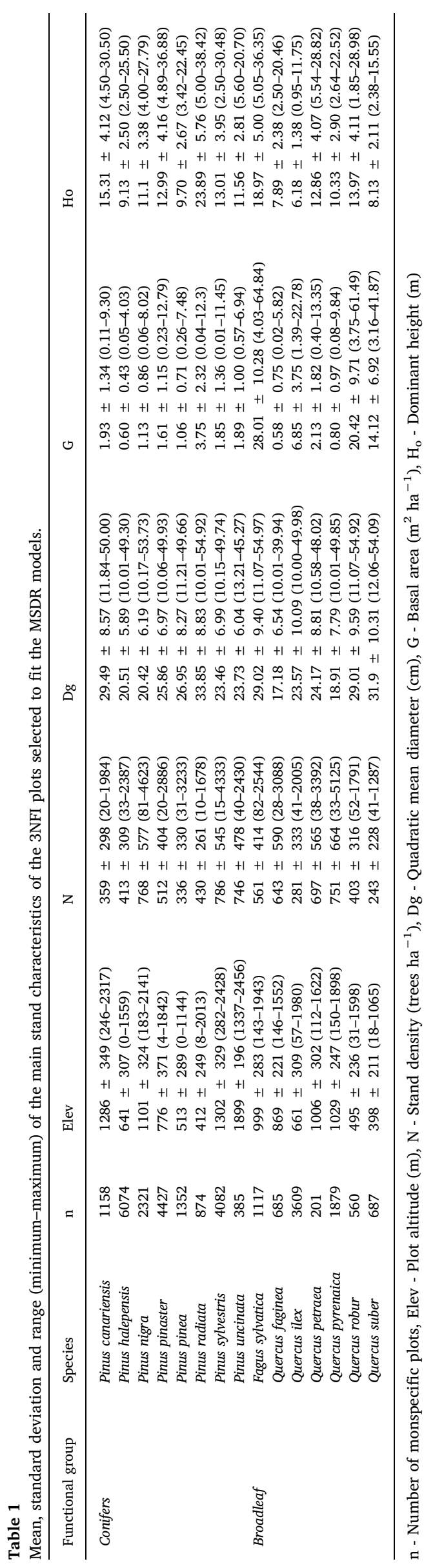


this study. 3NFI plots consist of four concentric circles with radii of $5,10,15$ and $25 \mathrm{~m}$, in each of which multiple tree-level variables for all trees over 7.5, 12.5, 22.5 and $42.5 \mathrm{~cm}$ diameter at breast height $(1.3 \mathrm{~m})$, respectively, were recorded from 1997 to 2007 (Herrero and Bravo, 2012; Alberdi et al., 2016). Expansion factors were used to estimate stand variables from individual tree variables, such as density $(\mathrm{N})$, quadratic mean diameter (Dg), basal area (G) and dominant height (Ho). 3NFI plots located in monospecific stands of different coniferous and broadleaf species (Table 1) were selected. Plots were considered monospecific when the main species accounted for more than $90 \%$ of the total basal area. Low-density plots were discarded under the hypothesis that the MSDR depends on the climatic conditions following the methodology proposed by Condés et al. 2017. In addition, plots with quadratic mean diameter outside the $10-60 \mathrm{~cm}$ range were also dismissed to avoid including under-represented stands. Climatic data were obtained from Worldclim 2 (Fick and Hijmans, 2017). Worldclim 2 is a high-resolution global geo-database (30 arc seconds or $\sim 1 \mathrm{~km}$ at equator) of monthly average data gathered from extensive climate observations and the NASÁs Shuttle Radar Topography Mission (SRTM). Climatic variables of annual, seasonal and monthly temperature and precipitation records over a 30-year climate normal period (1970-2000) were included. Variables related to temperature were expressed in Kelvin degrees (K), since the logarithmic models fitted in this study do not accept negative values for independent variables. The Temperature Annual Range (TAR), expressed as the difference between the maximum and minimum annual temperature, and the De Martonne Index (M) were also calculated. The De Martonne Index (De Martonne, 1926), calculated as $P /(T+10)$ (where $P$ is the total annual precipitation in $\mathrm{mm}$, and $\mathrm{T}$ is the mean annual temperature in ${ }^{\circ} \mathrm{C}$ ), is a climatic index commonly used to describe aridity or drought in a given area (Bielak et al., 2014; Condés et al., 2017; Aguirre et al., 2018). Potential evapotranspiration data from the Global Potential Evapotranspiration Geospatial Database (Trabucco and Zomer, 2009) were also considered in this study. Altogether, 35 climatic variables were used in this study to characterize climate annually and seasonally (Table 2). All climatic variables were derived from selected monospecific plots using GIS software and plot-specific latitude and longitude. Supplementary Tables S1 and S2 provide a complete statistical summary of the climatic variables used in this study.

\subsection{Data modeling}

Firstly, basic MSDR models (without climatic influence) were fitted

Table 2

List of climatic variables used in this study.

\begin{tabular}{|c|c|}
\hline Variable & Definition \\
\hline $\mathrm{T}$ & Annual Mean Temperature (Kelvin degrees) \\
\hline $\mathrm{Ti}$ & Mean Temperature (Kelvin) of the i Season $(i=1,2,3,4)$ \\
\hline MNT & Annual Mean Minimum Temperature (Kelvin degrees) \\
\hline $\mathrm{MNT}_{\mathrm{i}}$ & Minimum Temperature (Kelvin degrees) of the i Season $(i=1,2,3,4)$ \\
\hline MXT & Annual Mean Maximum Temperature (Kelvin degrees) \\
\hline $\mathrm{MXT}_{\mathrm{i}}$ & Maximum Temperature (Kelvin degrees) of the i Season $(i=1,2,3,4)$ \\
\hline MXTWM & Maximum Temperature of Warmest Month (Kelvin degrees) \\
\hline MNTCM & Minimum Temperature of Coldest Month (Kelvin degrees) \\
\hline TAR & Temperature Annual Range (Kelvin degrees) (MXTWM - MNTCM) \\
\hline $\mathrm{P}$ & Total Annual Precipitation (mm) \\
\hline$P_{i}$ & Total Precipitation $(\mathrm{mm})$ of the $\mathrm{i}$ Season $(\mathrm{i}=1,2,3,4)$ \\
\hline PWM & Precipitation of Wettest Month (mm) \\
\hline PDM & Precipitation of Driest Month (mm) \\
\hline M & Annual De Martonne Index $\left(\mathrm{mm}{ }^{\circ} \mathrm{C}^{-1}\right)$ \\
\hline $\mathrm{M}_{\mathrm{i}}$ & De Martonne Index $\left(\mathrm{mm}^{\circ} \mathrm{C}^{-1}\right)$ of the i Season $(\mathrm{i}=1,2,3,4)$ \\
\hline PET & Annual Potential Evapotranspiration (mm) \\
\hline $\mathrm{PET}_{\mathrm{i}}$ & Potential Evapotranspiration $(\mathrm{mm})$ of the i Season $(\mathrm{i}=1,2,3,4)$ \\
\hline
\end{tabular}

i: 1 = Autumn (October, November, December), 2 = Winter (January, February, March), 3 = Spring (April, May, June), 4 = Summer (July, August, September) using Reineke's (1933) equation (Eq. (1)) after natural logarithmic transformation (Eq. (2)), to obtain species-specific coefficients:

$N_{\max }=\alpha_{0}^{\prime} \cdot D g^{\beta 0}$

$\ln \left(N_{\max }\right)=\alpha_{0}+\beta_{0} \cdot \ln (D g)$

where: $\mathrm{N}_{\max }$ is the maximum density (trees $\mathrm{ha}^{-1}$ ), $\mathrm{Dg}$ is the mean quadratic diameter $(\mathrm{cm}), \alpha_{0}$ is the species-specific intercept and $\beta_{0}$ is the species-specific slope to be estimated.

Basic MSDR coefficients were estimated by linear quantile regression for each species, using the quantreg R package (Koenker, 2015) on $R$ software ( $R$ Core Team, 2018). Models were fitted for the upper quantiles $\left(95^{\text {th }}, 97.5^{\text {th }}\right.$ and $\left.99^{\text {th }}\right)$ since the MSDR is a limiting boundary (Ducey and Knapp, 2010; Aguirre et al., 2018). Climate-dependent MSDR models were then fitted by species, to analyze the influence of climate on MSDR and maximum stand carrying capacity. Climate-dependent coefficients were obtained for each climatic variable using linear quantile regression, by expanding the coefficients in Eq. (2) as a function of climate:

$\ln \left(N_{\max }\right)=\alpha_{0}+\alpha_{1} \cdot \ln (C \lim )+\left(\beta_{0}+\beta_{1} \cdot C \lim \right) \cdot \ln (D g)$

where: Clim is a climatic variable from Table 2 and $\alpha_{0}, \alpha_{1}, \beta_{0}$ and $\beta_{1}$ are the model parameters to be estimated.

As a result, 35 climate-dependent models were fitted for each species at the same quantiles as the basic MSDR models. The F-test, based on the extra sum of squares principle (Ratwosky, 1983), was used to test any statistically significant improvement (at $\alpha=0.05$ significance level) of these models over the basic models. Finally, significant climate-dependent models were arranged based on the Akaike Information Criterion (AIC) and pseudo- $\mathrm{R}^{2}$ for quantile regression (Koenker and Machado, 1999), to determine the climatic variables that most affect MSDR by species.

\subsection{Climatic influence on maximum stand carrying capacity}

Maximum stand carrying capacity was expressed as the Maximum Stand Density Index (SDI $\mathrm{max}_{\mathrm{x}}$ ), derived from Reineke's (1933) equation. Reference values for $\mathrm{SDI}_{\max }\left(\mathrm{SDI}_{\operatorname{maxREF}}\right)$ were calculated by species, using estimated coefficients from basic MSDR models (Eq. (2)).

$S D I_{\max R E F}=e^{[\alpha 0+\beta 0 \ln (25)]}$

In a similar way, estimated coefficients from the selected climatedependent models were used to calculate the climate-dependent $\mathrm{SDI}_{\max }$ by species [Eq. (5)]:

$S D I_{\max }(C \lim )=e^{[(\alpha 0+\alpha 1 \ln (C \lim ))+(\beta 0+\beta 1 \cdot C \lim ) \cdot \ln (25)]}$

where $S D I_{\max }$ (Clim) is the function of the maximum stand carrying capacity for each species and climatic variable Clim and $\alpha 0, \alpha 1, \beta 0$ and $\beta 1$ are the estimated coefficients from climate-dependent MSDR models.

To visually detect trends in $S D I_{\max }$ variation, $S D I_{\max }$ (Clim) values were obtained and plotted along the range of values (percentiles 1 to 99) for each climatic variable selected. Then, the $Q$ index was proposed in order to quantify the $\mathrm{SDI}_{\max }$ variation a species shows in a region along a range of different climatic conditions. First, the difference between $S D I_{\max }(\mathrm{Clim})$ values obtained from the climate-dependent models (Eq. (5)) with respect to species-specific $\mathrm{SDI}_{\text {maxREF }}$ obtained from (Eq. (4)) was considered (Fig. 1). By integrating them between the $1^{\text {st }}$ and the $99^{\text {th }}$ percentile of the climatic variable, the area between the $S D I_{\text {max }}$ (Clim) function and the $y=S_{\text {maxREF }}$ line was then determined. This area is known as the Surface Between Curves (SBC). To relativize the SBC to the $\mathrm{SDI}_{\text {maxREF }}$ reference value and make it comparable among species and climatic drivers, the $\mathrm{Q}$ index was calculated as shown in Eq. (6). 


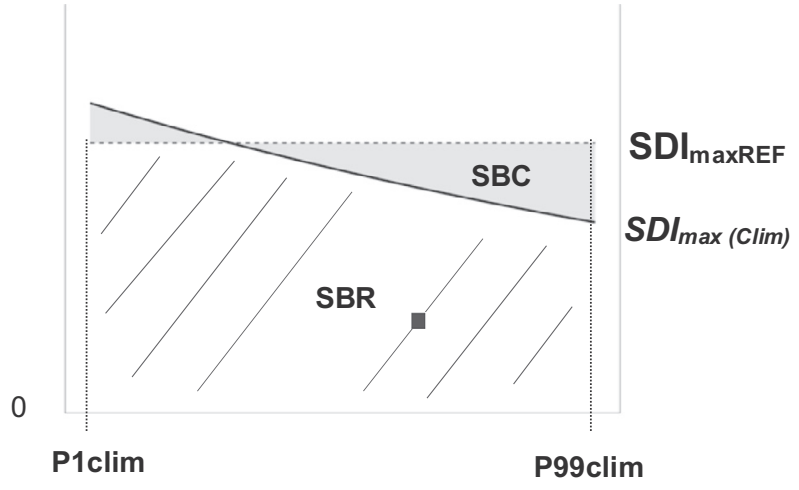

Fig. 1. Graphical representation of the $Q$ index.

$Q$ index $=\frac{S B C}{S B R}$

where SBR (Surface Below Reference) represents the area below the reference line $y=\mathrm{SDI}_{\mathrm{maxREF}}$, i.e., $\mathrm{SBR}=\mathrm{SDI}_{\mathrm{maxREF}} *(\mathrm{P} 99 \mathrm{clim}-$ P1clim) and P1clim and P99clim are the $1^{\text {st }}$ and the $99^{\text {th }}$ percentile of the climatic variable.

\section{Results}

\subsection{Basic MSDR models}

The intercept $\left(\alpha_{0}\right)$ and slope $\left(\beta_{0}\right)$ of the basic MSDRs were highly significant $(\mathrm{p}<0.001)$ for all the coniferous (Table 3 ) and broadleaf species (Table 4) studied. Since $\mathrm{SDI}_{\text {maxREF }}$ estimate results were very low for the $95^{\text {th }}$ and very high for the $99^{\text {th }}$ quantiles compared to similar studies, the $97.5^{\text {th }}$ quantile was selected as the reference for each model, to allow for comparison of results among all the species studied. The results of the basic MSDR models fitted at these quantiles are available in Supplementary Table S3. Of the coniferous species, Pinus pinea $(-2.1855)$ and Pinus pinaster $(-1.9063)$ presented the steepest slopes of the basic MSDRs, while Pinus sylvestris $(-1.7524)$ and Pinus uncinata $(-1.7336)$ presented the flattest slopes. Estimated SDI maxREF $_{\text {an }}$ values for the coniferous species ranged from 526 (Pinus halepensis) to 1178 (Pinus radiata) trees per hectare (Table 5). In general, broadleaf species presented smaller maximum stand carrying capacities (from 319 to 995 trees per hectare) than coniferous species. Results for these species fell along a gradient; Quercus ilex $(-2.0951)$ had higher intercepts and shallower slopes, followed by Quercus suber, Fagus sylvatica, Quercus pyrenaica, Quercus faginea, Quercus petraea, and finally Quercus robur with the least pronounced slope $(-1.6698)$ (Table 4). Basic MSDR trajectories are shown by species in Figs. 2 and 3.

\subsection{Climate-dependent MSDR models}

Coefficients for the best climate-dependent MSDR models fitted at the $97.5^{\text {th }}$ quantile are presented in Table 3 (coniferous species) and Table 4 (broadleaf species). A complete list of all fitted climate-dependent MSDR models is available in Supplementary Table S4. The results indicated that climatic variables related to temperature better explained the influence of climate on MSDR, for both conifers and broadleaf species. Specifically, seasonal $\left(\mathrm{MXT}_{\mathrm{i}}\right)$ and annual (MXT) maximum temperatures were the most representative climatic variables among the 35 studied. Climate-dependent models including Maximum Summer Temperature (MXT4) were selected in 8 (4 conifer and 4 broadleaf) of the 15 species, followed by models including Maximum Spring Temperature (MXT3), Maximum Temperature of the Warmest Month (MXTWM) and Maximum Annual Temperature (MXT). For all species excepting, spring and summer consistently appeared as key periods, with significant interaction between climate and MSDR.
Among the conifers studied, the models selected for Pinus halepensis, Pinus nigra, Pinus pinaster and Pinus sylvestris indicated maximum temperatures as key variables for explaining climatic influence on MSDR. In contrast, aridity, precipitation and potential evapotranspiration was the variables that most influenced MSDR for Pinus canariensis, Pinus pinea, Pinus radiata and Pinus uncinata (Table 3 ). Only three climatic models were significant for Pinus radiata, which may be due to a high concentration of selected monospecific plots in a specific area without a wide climatic variability. Among the broadleaf species studied, temperature was also found to be a key driver affecting MSDR, since most of the climate-dependent models selected were related to these variables (Table 4). Maximum temperatures were found to be key drivers for Quercus petraea and Quercus pyrenaica, while Quercus robur was affected by minimum temperatures. The best models for Quercus ilex and Quercus suber indicated that potential evapotranspiration played an important role in explaining changes in MSDR and SDI max $_{\text {for }}$ for the species. Aridity also influenced the MSDR of Fagus sylvatica and Quercus faginea according to the best models for these species. However, the other selected models for Quercus faginea were related to changes in summer temperatures. For all species, selected climate-dependent MSDR significantly improved the goodness of fit, in terms of AIC and pseudo- $\mathrm{R}^{2}$, compared to the basic models. Among the coniferous species, Pinus pinea and Pinus radiata selected models showed the highest pseudo- $\mathrm{R}^{2}$ with values close to 0.40 (Table 3). Pinus canariensis models showed the highest AIC reduction ( $\triangle$ AIC ranging -7 and $-11.3 \%$ ) with respect to the basic MSDR model. For Pinus nigra, Pinus sylvestris and Pinus radiata, however, inclusion of a climatic variable in the basic MSDR model did little to improve its efficiency ( $\Delta$ AIC close to $-2 \%$ ). Compared to conifers, broadleaf results generally presented higher pseudo- $\mathrm{R}^{2}$ values and greater differences in AIC with respect to the basic MSDR models (Table 4). Climate-dependent models for Fagus sylvatica, Quercus ilex and Quercus suber presented the highest pseudo$\mathrm{R}^{2}$ values among the 15 species.

\subsection{Climatic influence on maximum stand carrying capacity}

Climate was found to have significant influence on MSDR, and therefore on the maximum stand carrying capacity ( $\mathrm{SDI}_{\max }$ ). The best climate-dependent models for each species revealed a common trend in $\mathrm{SDI}_{\text {max }}$ variation for coniferous and broadleaf species (Fig. 4 and Fig. 5). The results indicated that higher $\mathrm{SDI}_{\max }$ values were negatively linked to temperature and positively linked to precipitation (Table 5). Accordingly, higher maximum temperatures led to smaller $\mathrm{SDI}_{\max }$ values for Pinus nigra, Pinus pinaster, Fagus sylvatica, Quercus faginea and Quercus petraea, while increments in precipitation led to higher $\mathrm{SDI}_{\max }$ values for Pinus canariensis and Pinus pinea. A particular behaviour of $\mathrm{SDI}_{\max }$ variation was found for Pinus pinea and Pinus radiata, with a $S D I_{\max }$ (Clim) distribution presenting a parabolic shape with a minimum reached close to the median of the P4 (Pinus pinea) and PET3 (Pinus radiata) range.

$Q$ indexes obtained for conifers (Tables 3-5) showed that the highest variations in $\mathrm{SDI}_{\max }$ across different climatic conditions were obtained for Pinus canariensis (0.305), followed by Pinus pinea (0.262). On the contrary, the lower values of $\mathrm{Q}$ index were found for Pinus halepensis (0.063) and Pinus radiata (0.058). Among broadleaf species, the lowest Q index was found for Fagus sylvatica (0.085) and the highest for Quercus faginea (0.315). The rest of the Quercus species presented similar values ranging from 0.11 to 0.24 .

\section{Discussion}

In this study, a significant influence of climate on the MSDR was found for the 15 Mediterranean species studied. Our results highlighted the need to consider different specific climatic variables to better predict this climatic influence as previous researchers (Aguirre et al. 2018; Condés et al. 2017; Brunet-Navarro et al. 2016; Charru et al., 2012). 
Table 3

Species-specific coefficients, SDI $_{\max }$ estimates and goodness of fit in terms of Akaike's Information Criterion (AIC) and pseudo- $\mathrm{R}^{2}$ coefficient for the basic and the top five climate-dependent MSDR models fitted by linear quantile regression (97.5th quantile) for coniferous species.

\begin{tabular}{|c|c|c|c|c|c|c|c|c|}
\hline Species & Model & $\alpha_{0}$ & $\alpha_{1}$ & $\beta_{0}$ & $\beta_{1}$ & AIC & pseudo- $\mathrm{R}^{2}$ & Q index \\
\hline \multirow[t]{6}{*}{ Pinus canariensis } & basic & 12.672 *** & - & $-1.8226 * * *$ & - & 2616.9 & 0.3378 & - \\
\hline & $\mathrm{P} 1$ & $3.639 * * *$ & $2.448 * * *$ & $-2.0891 * * *$ & - & 2320.8 & 0.4178 & 0.305 \\
\hline & PWM & $4.176 * * *$ & $2.059 * * *$ & $-1.9567 * * *$ & - & 2347.4 & 0.4111 & 0.251 \\
\hline & $\mathrm{P}$ & $13.161 * * *$ & - & $-2.6082 * * *$ & $0.0015 * * *$ & 2364.4 & 0.4067 & 0.245 \\
\hline & $\mathrm{P} 2$ & $12.989 * * *$ & - & $-2.3961 * * *$ & $0.0075 * * *$ & 2420.9 & 0.3921 & 0.189 \\
\hline & M1 & $11.738 * * *$ & $1.061 * * *$ & $-1.8500 * * *$ & - & 2431.5 & 0.3893 & 0.189 \\
\hline \multirow[t]{6}{*}{ Pinus halepensis } & basic & $11.982 * * *$ & - & $-1.7760 * * *$ & - & 12622.5 & 0.3388 & - \\
\hline & M & $9.241 * * *$ & $0.886 * * *$ & $-1.5559 * * *$ & $-0.0095 * *$ & 12325.5 & 0.3549 & 0.063 \\
\hline & MXT3 & $96.948 * * *$ & $-14.977 * * *$ & $-1.7045 * * *$ & - & 12368.1 & 0.3526 & 0.079 \\
\hline & MXT4 & $105.595 * * *$ & $-16.445 * * *$ & $-1.7171 * * *$ & - & 12383.7 & 0.3517 & 0.077 \\
\hline & MXTWM & $100.504 * * *$ & $-15.542 * * *$ & $-1.7134 * * *$ & - & 12394.4 & 0.3512 & 0.073 \\
\hline & PWM & $8.722 * * *$ & $0.784 * * *$ & $-1.6057 * * *$ & -0.0026 * & 12401.9 & 0.3509 & 0.051 \\
\hline \multirow[t]{6}{*}{ Pinus nigra } & basic & $12.756 * * *$ & - & $-1.8346 * * *$ & - & 5117.9 & 0.2965 & - \\
\hline & MXT3 & $140.953 * * *$ & $-22.536 * * *$ & $-1.9324 * * *$ & - & 5010.9 & 0.3128 & 0.123 \\
\hline & MXT & $154.667 * * *$ & $-24.995 * * *$ & $-1.9154 * * *$ & - & 5028.5 & 0.3102 & 0.119 \\
\hline & MXT4 & $104.610 * * *$ & $-16.094 * *$ & $-1.9119 * * *$ & - & 5045.9 & 0.3076 & 0.091 \\
\hline & MXT2 & 13.019 *** & - & $5.7005 * * *$ & $-0.0268 * * *$ & 5046.7 & 0.3075 & 0.119 \\
\hline & $\mathrm{P} 2$ & $11.821 * * *$ & $0.290 * * *$ & $-1.8973 * * *$ & - & 5047.8 & 0.3073 & 0.098 \\
\hline \multirow[t]{6}{*}{ Pinus pinaster } & basic & $13.096 * * *$ & - & $-1.9063 * * *$ & - & 10593,0 & 0.2716 & - \\
\hline & MXT & $13.446 * * *$ & - & $4.1770 * * *$ & $-0.0213 * * *$ & 10229,0 & 0.3011 & 0.129 \\
\hline & MXT3 & $13.365 * * *$ & - & $3.5759 * * *$ & $-0.0190 * * *$ & 10241.6 & 0.3001 & 0.128 \\
\hline & $\mathrm{T} 3$ & $13.324 * * *$ & - & $3.9110 * * *$ & $-0.0206 * * *$ & 10296.4 & 0.2958 & 0.121 \\
\hline & MXT4 & $13.462 * * *$ & - & $2.6955 * * *$ & $-0.0159 * * *$ & 10307.5 & 0.2949 & 0.114 \\
\hline & MXT2 & $13.389 * * *$ & - & $3.3318 * * *$ & $-0.0187 * * *$ & 10317.1 & 0.2941 & 0.114 \\
\hline \multirow[t]{6}{*}{ Pinus pinea } & basic & $13.562 * * *$ & - & $-2.1855 * * *$ & - & 3270.9 & 0.3887 & - \\
\hline & P4 & $15.072 * * *$ & $-0.460 *$ & $-2.4379 * * *$ & $0.0093 * * *$ & 3139.5 & 0.4185 & 0.262 \\
\hline & M4 & $13.531 * * *$ & $-0.467 * *$ & $-2.4556 * * *$ & $0.2919 * * *$ & 3144,0 & 0.4176 & 0.257 \\
\hline & $\mathrm{P}$ & $13.213 * * *$ & - & $-2.2271 * * *$ & $0.0003 * *$ & 3210.7 & 0.4026 & 0.131 \\
\hline & TAR & 77.368 ** & $-11.127 *$ & $-2.2790 * * *$ & - & 3213.2 & 0.4020 & 0.143 \\
\hline & M & 13.304 *** & - & $-2.2518 * * *$ & $0.0077 *$ & 3216.7 & 0.4013 & 0.155 \\
\hline \multirow[t]{4}{*}{ Pinus radiata } & basic & $12.947 * * *$ & - & $-1.8254 * * *$ & - & 1432.8 & 0.3723 & - \\
\hline & PET3 & $110.968 * * *$ & $-21.507 * * *$ & $-8.0490 * * *$ & $0.0652 * * *$ & 1402.4 & 0.3845 & 0.058 \\
\hline & PET4 & 88.959 *** & $-16.269 * *$ & $-6.5496 * * *$ & $0.0441 * *$ & 1409.2 & 0.3821 & 0.062 \\
\hline & PET1 & $6.920 * *$ & $1.675 *$ & $-1.3894 * * *$ & $-0.0119 * *$ & 1421.2 & 0.3778 & 0.020 \\
\hline \multirow[t]{6}{*}{ Pinus sylvestris } & basic & $12.685 * * *$ & - & $-1.7524 * * *$ & - & 7718.9 & 0.368 & - \\
\hline & TAR & $66.470 * * *$ & $-9.442 * * *$ & $-1.7478 * * *$ & - & 7594.7 & 0.3777 & 0.078 \\
\hline & MNTCM & $617.791 * * *$ & $-108.147 * * *$ & $-40.0934 * * *$ & $0.1425 * * *$ & 7630.1 & 0.3751 & 0.109 \\
\hline & MXTWM & $74.540 * * *$ & $-10.872 * * *$ & $-1.7675 * * *$ & - & 7637.6 & 0.3744 & 0.075 \\
\hline & MXT4 & $71.686 * * *$ & $-10.376 * * *$ & $-1.7699 * * *$ & - & 7643.9 & 0.3739 & 0.073 \\
\hline & MXT3 & $58.945 * * *$ & $-8.154 * * *$ & $-1.7767 * * *$ & - & 7653,0 & 0.3732 & 0.064 \\
\hline \multirow[t]{6}{*}{ Pinus uncinata } & basic & $12.519 * * *$ & - & $-1.7336 * * *$ & - & 556.6 & 0.4414 & - \\
\hline & PET3 & $12.918 * * *$ & - & $-1.6378 * * *$ & $-0.0031 * *$ & 534.6 & 0.4586 & 0.068 \\
\hline & PET4 & $16.777 * * *$ & $-0.838 * * *$ & $-1.8979 * * *$ & - & 535.5 & 0.4580 & 0.063 \\
\hline & PET & $12.899 * * *$ & - & $-1.6288 * * *$ & $-0.0004 * *$ & 535.6 & 0.4578 & 0.108 \\
\hline & PET2 & $12.908 * * *$ & - & $-1.6784 * * *$ & $-0.0077 * *$ & 536.7 & 0.4571 & 0.062 \\
\hline & P2 & 11.386 *** & $0.364 * * *$ & $-1.9112 * * *$ & - & 538.1 & 0.4561 & 0.052 \\
\hline
\end{tabular}

$* * * \mathrm{p}<0.001 ; * * \mathrm{p}<0.01 ; * \mathrm{p}<0.05$

Note: $<5$ significant climate-dependent MSDR models were found for Pinus radiata and Pinus uncinata.

However, exact agreement with previously published studies (Aguirre et al. 2018; Brunet-Navarro et al. 2016) could not be expected for the same species and areas regarding the key drivers affecting the MSDR and the way they impact the maximum stand carrying capacity estimations. In addition, different approaches (Condés et al., 2017; Riofrío et al. 2016) in selecting monospecific plots could derive in a different plot samples and therefore in different results. As well as this, regarding the climate database, although other databases could also be used such as Gonzalo Jimenez (2010), the most updated (1970-2000) time period offered by WorldClim2 available for the whole study area was selected in order to consider a suitable range of different climatic conditions with high resolution (Abatzoglou et al. 2018; Poggio et al. 2018; Panagos et al. 2017).

\subsection{Basic MSDRs and $S D I_{\max }$ reference values}

Our findings showed significant differences in the coefficients of the basic MSDRs (Tables 3 and 4), confirming intra- and inter-specific variability among the selected coniferous and broadleaf species
(Vospernik and Sterba, 2015). The range of the slopes fitted in the basic MSDR models for the coniferous species agreed with findings reported by Charru et al. (2012) and Aguirre et al. (2018). Those authors found shallower slopes for Pinus sylvestris than for other pines in Spain and France, showing the great ability of this species to grow and survive amidst intra-specific competition (Zeide, 1987; Pretzsch and Biber, 2005). The development of wide crown areas at older ages could explain the extreme value of the slope for Pinus pinea (Barbeito et al., 2008). Among the broadleaf species, Quercus suber (-1.9674) and Quercus ilex $(-2.0951)$ presented the steepest MSDR slopes and the smallest $\mathrm{SDI}_{\max }$ estimates. These outputs may be due to the ability of these species to support a great leaf area, so that fewer individuals are needed to fully occupy a stand (Woodall et al., 2005).

The SDI maxREF values estimated in this study were compared to prior reference values from published studies in similar areas, to test the consistency of our models (Table 6). Agreement was generally good, as stands dominated by conifers showed relatively higher SDI maxREF values when compared to those dominated by broadleaf species. The distinct values obtained in other studies for the same species may be due to the 
Table 4

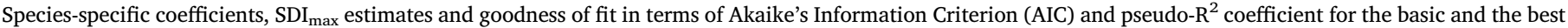
climate-dependent MSDR models fitted by linear quantile regression ( 97.5 th quantile) for broadleaf species.

\begin{tabular}{|c|c|c|c|c|c|c|c|c|}
\hline Species & Model & $\alpha_{0}$ & $\alpha_{1}$ & $\beta_{0}$ & $\beta_{1}$ & AIC & pseudo- $\mathrm{R}^{2}$ & Q index \\
\hline \multirow[t]{6}{*}{ Fagus sylvatica } & basic & $13.170 * * *$ & - & $-1.9471 * k *$ & - & 1577.1 & 0.5137 & - \\
\hline & МХT3 & $12.870 * * *$ & - & $2.0880 * * *$ & $-0.0137 * * *$ & 1507.5 & 0.5290 & 0.085 \\
\hline & $\mathrm{T} 3$ & $12.813 * * *$ & - & $2.0872 *$ & $-0.0138 * * *$ & 1510.2 & 0.5285 & 0.085 \\
\hline & MXT2 & $75.624 * * *$ & $-11.138 * * *$ & $-1.8360 * * *$ & - & 1512.2 & 0.5281 & 0.070 \\
\hline & PET1 & $12.911 * * *$ & - & $-1.5935 * * *$ & $-0.0085 * * *$ & 1514.5 & 0.5276 & 0.061 \\
\hline & M1 & $12.133 * * *$ & $0.671 * * *$ & $-2.0013 * * *$ & - & 1514.9 & 0.5275 & 0.135 \\
\hline \multirow[t]{6}{*}{ Quercus faginea } & basic & $12.097 * * *$ & - & $-1.7055 * * *$ & - & 2003.5 & 0.1811 & - \\
\hline & MXTWM & $247.037 * * *$ & $-41.233 * * *$ & $-1.7874 * * *$ & - & 1883.7 & 0.2508 & 0.315 \\
\hline & TAR & $12.606 * * *$ & - & $12.9044 * * *$ & $-0.0495 * * *$ & 1886.9 & 0.2490 & 0.350 \\
\hline & MXT4 & $254.074 * * *$ & $-42.519 * * *$ & $-1.7485 * * *$ & - & 1899.6 & 0.2420 & 0.315 \\
\hline & $\mathrm{T} 4$ & $271.627 * * *$ & $-45.750 * * *$ & $-1.6856 * * *$ & - & 1910.6 & 0.2359 & 0.303 \\
\hline & M & $9.667 * * *$ & $0.812 * * *$ & $-1.8657 * * *$ & - & 1915.9 & 0.2329 & 0.188 \\
\hline \multirow[t]{6}{*}{ Quercus ilex } & basic & $12.508 * * *$ & - & $-2.0951 * * *$ & - & 8099.8 & 0.5025 & - \\
\hline & РЕT3 & $11.777 * * *$ & - & $-1.3094 * * *$ & $-0.0044 * * *$ & 7398.6 & 0.5487 & 0.211 \\
\hline & PET & $11.773 * * *$ & - & $-1.4050 * * *$ & $-0.0004 * * *$ & 7449.7 & 0.5455 & 0.207 \\
\hline & MXT3 & $11.899 * * *$ & - & $5.0064 * * *$ & $-0.0234 * * *$ & 7474.1 & 0.5440 & 0.215 \\
\hline & MXTWM & $11.969 * * *$ & - & $4.7651 * * *$ & $-0.0223 * * *$ & 7484.2 & 0.5433 & 0.172 \\
\hline & PET2 & $11.865 * * *$ & - & $-1.5025 * * *$ & $-0.0087 * * *$ & 7491.1 & 0.5429 & 0.159 \\
\hline \multirow[t]{6}{*}{ Quercus petraea } & basic & $12.277 * * *$ & - & $-1.6777 * * *$ & - & 431.3 & 0.3877 & - \\
\hline & MXT & $-489.861 * * *$ & $88.759 * * *$ & $36.5003 * * *$ & $-0.1334 * * *$ & 357.6 & 0.4954 & 0.242 \\
\hline & MXT4 & $12.593 * * *$ & - & $9.0312 * * *$ & $-0.0370 * * *$ & 358.5 & 0.4917 & 0.247 \\
\hline & MXT3 & $12.615 * * *$ & - & $7.5139 * * *$ & $-0.0323 * * *$ & 360,0 & 0.4899 & 0.230 \\
\hline & MXTWM & $12.382 * * *$ & - & 8.8624 *** & $-0.0360 * * *$ & 360.8 & 0.4889 & 0.227 \\
\hline & $\mathrm{T} 4$ & $12.674 * * *$ & - & $11.0925 * * *$ & $-0.0446 * k *$ & 361.6 & 0.4878 & 0.240 \\
\hline \multirow[t]{6}{*}{ Quercus pyrenaica } & basic & $12.271 * * *$ & - & $-1.7203 * * *$ & - & 4718.4 & 0.2962 & - \\
\hline & $\mathrm{T} 4$ & $-187.581 *$ & $35.255 *$ & 17.946 *** & $-0.0679 * * *$ & 4537.2 & 0.3300 & 0.213 \\
\hline & MNT4 & $12.312 * * *$ & - & $7.1163 * * *$ & $-0.0309 * * *$ & 4566.5 & 0.3244 & 0.186 \\
\hline & MXTWM & $12.335 * * *$ & - & $5.6320 * * *$ & $-0.0250 * * *$ & 4570,0 & 0.3238 & 0.191 \\
\hline & MXT3 & $-310.973 *$ & 57.023 * & $24.1039 * *$ & $-0.0892 * * *$ & 4577.6 & 0.3228 & 0.204 \\
\hline & MXT4 & $12.328 * * *$ & - & $5.5596 * * *$ & $-0.0248 * * *$ & 4578.1 & 0.3223 & 0.182 \\
\hline \multirow[t]{6}{*}{ Quercus robur } & basic & $12.043 * * *$ & - & $-1.6698 * * *$ & - & 1017.7 & 0.4394 & - \\
\hline & MNT3 & $-795.789 * * *$ & $143.317 * * *$ & $49.1578 * * *$ & $-0.1812 * * *$ & 974.7 & 0.4624 & 0.120 \\
\hline & MNT & $-820.659 * * *$ & $147.740 * * *$ & $51.1787 * * *$ & $-0.1885 * * *$ & 981.1 & 0.4594 & 0.125 \\
\hline & MNT2 & $-605.574 * * *$ & $109.939 * * *$ & $37.8316 * * *$ & $-0.1435 * * *$ & 985.5 & 0.4572 & 0.123 \\
\hline & MNT4 & $-1112.201 * * *$ & $198.611 * * *$ & $70.2864 * * *$ & $-0.2505 * * *$ & 989.2 & 0.4554 & 0.131 \\
\hline & MNT1 & $-624.820 * *$ & $113.08 * *$ & $39.0364 * *$ & $-0.1458 * *$ & 993.6 & 0.4533 & 0.115 \\
\hline \multirow[t]{6}{*}{ Quercus suber } & basic & $12.704 * * *$ & - & $-1.9674 * * *$ & - & 1340.2 & 0.4839 & - \\
\hline & РЕT3 & $11.948 * * *$ & - & $-1.2349 * * *$ & $-0.0043 * * *$ & 1233.6 & 0.5231 & 0.176 \\
\hline & MXTWM & $12.097 * * *$ & - & $9.7879 * * *$ & $-0.0385 * k *$ & 1235.9 & 0.5223 & 0.208 \\
\hline & PET4 & $11.846 * * *$ & - & $-1.3656 * * *$ & $-0.0025 * * *$ & 1239.2 & 0.5211 & 0.150 \\
\hline & MXT4 & $-670.091 * *$ & $119.608 * *$ & $43.6583 * * *$ & $-0.1515 * * *$ & 1239.5 & 0.5217 & 0.147 \\
\hline & MXT3 & $12.343 * * *$ & - & $9.4775 * *$ & $-0.0384 * k *$ & 1243.8 & 0.5195 & 0.185 \\
\hline
\end{tabular}

$* * * \mathrm{p}<0.001 ; * * \mathrm{p}<0.01 ; * \mathrm{p}<0.05 ;$ ns non-significant

Table 5

$\mathrm{SDI}_{\max }$ estimates for the different percentiles of the selected climate variable (best climate-dependent model) and Q index for the species studied.

\begin{tabular}{|c|c|c|c|c|c|c|c|c|c|}
\hline \multirow[t]{2}{*}{ Functional Group } & \multirow[t]{2}{*}{ Species } & \multirow[t]{2}{*}{ Clim } & \multirow[t]{2}{*}{$\mathrm{SDI}_{\operatorname{maxREF}}$} & \multicolumn{5}{|c|}{$S D I_{\max }(\mathrm{Clim})$} & \multirow[t]{2}{*}{$Q$ index } \\
\hline & & & & $\mathrm{P}_{1}$ & $\mathrm{P}_{25}$ & $P_{50}$ & $\mathrm{P}_{75}$ & $\mathrm{P}_{99}$ & \\
\hline \multirow[t]{8}{*}{ Conifers } & Pinus canariensis & $\mathrm{P} 1$ & 903 & 351 & 536 & 768 & 1051 & 1388 & 0.305 \\
\hline & Pinus halepensis & M & 526 & 422 & 500 & 543 & 559 & 558 & 0.063 \\
\hline & Pinus nigra & MXT3 & 944 & 1204 & 1064 & 941 & 832 & 737 & 0.123 \\
\hline & Pinus pinaster & MXT & 1053 & 1353 & 1190 & 1046 & 920 & 809 & 0.129 \\
\hline & Pinus pinea & P4 & 683 & 700 & 632 & 756 & 982 & 1325 & 0.262 \\
\hline & Pinus radiata & PET3 & 1178 & 1355 & 1197 & 1116 & 1093 & 1120 & 0.058 \\
\hline & Pinus sylvestris & TAR & 1146 & 1342 & 1241 & 1148 & 1063 & 984 & 0.078 \\
\hline & Pinus uncinata & PET3 & 1031 & 1109 & 1043 & 981 & 923 & 869 & 0.068 \\
\hline \multirow[t]{7}{*}{ Broadleaves } & Fagus sylvatica & MXT3 & 995 & 1188 & 1093 & 1005 & 924 & 850 & 0.085 \\
\hline & Quercus faginea & MXTWM & 740 & 999 & 725 & 527 & 384 & 281 & 0.315 \\
\hline & Quercus ilex & PET3 & 319 & 496 & 409 & 337 & 278 & 229 & 0.211 \\
\hline & Quercus petraea & MXT & 969 & 1268 & 1001 & 787 & 616 & 480 & 0.242 \\
\hline & Quercus pyrenaica & $\mathrm{T} 4$ & 840 & 1021 & 838 & 686 & 561 & 458 & 0.213 \\
\hline & Quercus robur & MNT3 & 787 & 993 & 888 & 790 & 699 & 616 & 0.120 \\
\hline & Quercus suber & РET3 & 585 & 721 & 608 & 512 & 432 & 364 & 0.176 \\
\hline
\end{tabular}

P - Percentile 

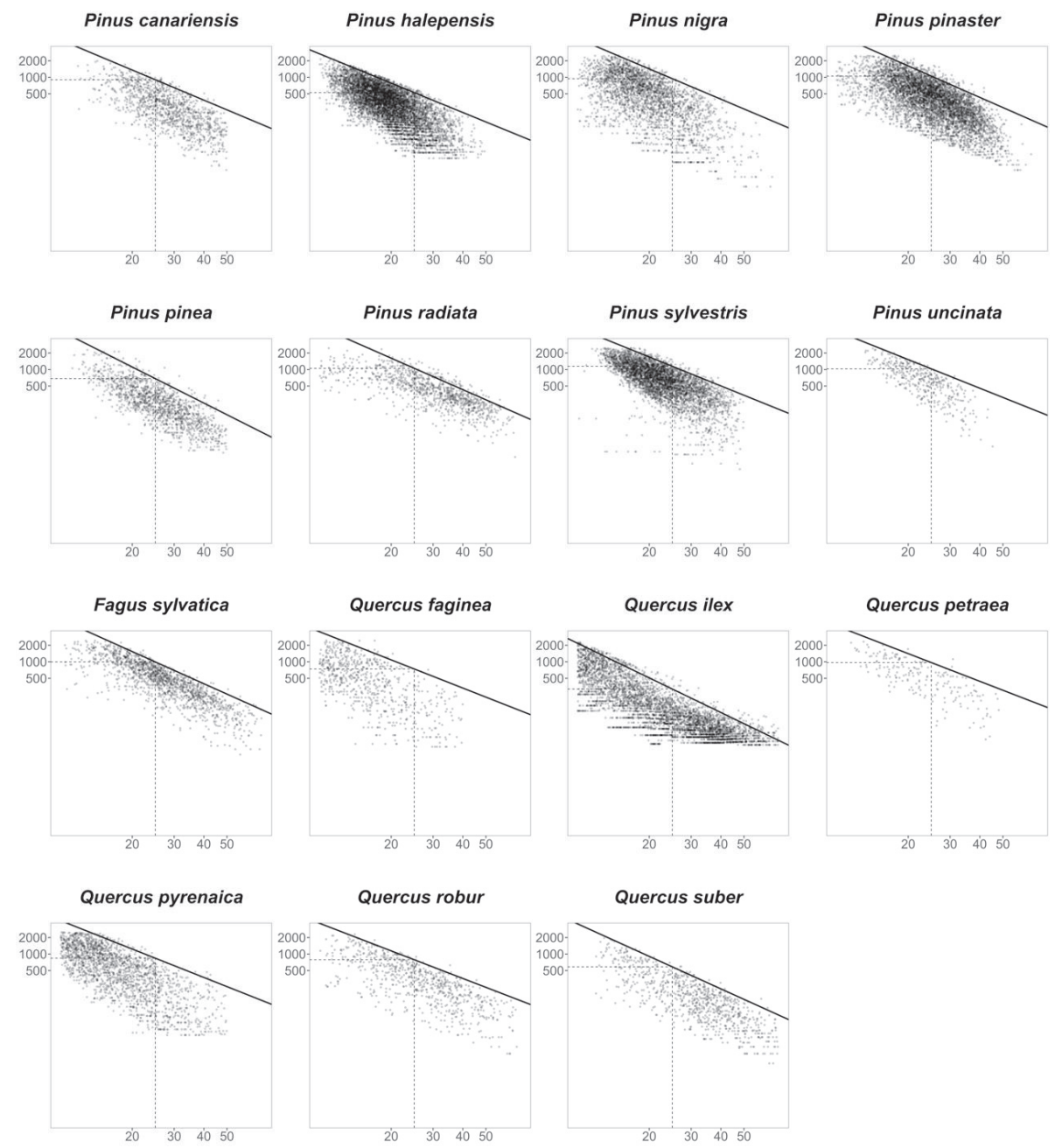

Fig. 2. Maximum Size-Density Relationships (MSDR) for the 15 coniferous and broadleaf species studied, plotted on a log-log scale for the selected monospecific stands. Self-thinning boundary lines fitted by quantile regression $\left(97.5^{\text {th }}\right.$ quantile) are represented by solid lines. Dashed lines represent the SDI maxkEF $_{\text {(maximum }}$ number of trees at a Dg reference of $25 \mathrm{~cm}$ ).

use of different approaches, methodologies and datasets (Hann, 2014). $\mathrm{SDI}_{\text {maxREF }}$ values were obtained by quantile regression in this study, whereas other relevant studies used different methodologies and types of statistical analysis, such as stochastic frontier analysis (e.g. Charru et al., 2012) or simple linear regression (e.g. Brunet-Navarro et al., 2016). Our findings were consistent with the theory that maximum stand density is known to be positively related to species shade tolerance (Jack and Long 1996, Woodall et al., 2005). However, SDI maxREF $_{\text {. }}$ values for light-demanding coniferous species such as Pinus pinaster, Pinus uncinata and Pinus sylvestris were unexpectedly high (Table 5), given their low shade-tolerance (Niinemets and Valladares, 2006). A similar trend was found by Andrews et al. (2018), who obtained smaller $\mathrm{SDI}_{\text {maxREF }}$ values for shade-tolerant species such as Fagus grandifolia and Acer saccharum than other light-demanding species in the northeastern United States. Prior to that, Dixon and Keyser (2017) reported similar results when analyzing the maximum stand density of 15 coniferous and broadleaf species in the same area. Higher maximum carrying capacities for light-demanding species such as Pinus sylvestris than for Fagus sylvatica or Quercus petraea were also obtained by Charru et al. (2012) and Toigo et al. (2018) in France. These results suggest the existence of other drivers affecting the maximum carrying capacity of the species studied, such as silvicultural objectives, plant phenology, crown allometry, available growing space or climate.

\subsection{Climatic influence on maximum stand carrying capacity}

In this study, a significant influence of climate in the MSDR and the maximum stand carrying capacity of 15 Mediterranean tree species was found. Reductions in the maximum carrying capacity were generally linked to warmer and drier conditions, though the climatic drivers that best explained the influence of the climate on MSDR and SDI $\mathrm{I}_{\max }$ varied for conifer and broadleaf species.

4.2.1. Climatic influence on maximum stand carrying capacity for coniferous species

Results from the climate-dependent MSDR models suggest that temperature could be the main driver affecting the maximum stand carrying capacity for conifers (Table 3). For Pinus nigra, Pinus pinaster and Pinus sylvestris, most of the selected climate-dependent models included seasonal temperatures, especially seasonal maximum (MXTi) temperatures. $S D I_{\max }$ (Clim) estimates for these species suggest that significant reductions in the maximum carrying capacity might be expected as temperatures increase, especially during the spring season (Fig. 4). Contrary to this trend, recent research on climate change and coniferous forest dynamics (Kurz-Besson et al., 2016) suggest that reducing the number of days below $5{ }^{\circ} \mathrm{C}$ could also improve the growth and vitality of these species by enhancing processes such as winter photosynthesis (Rathgeber et al., 2005), cambium and xylem formation (Vieira et al., 2014) and the development of deeper roots during the 


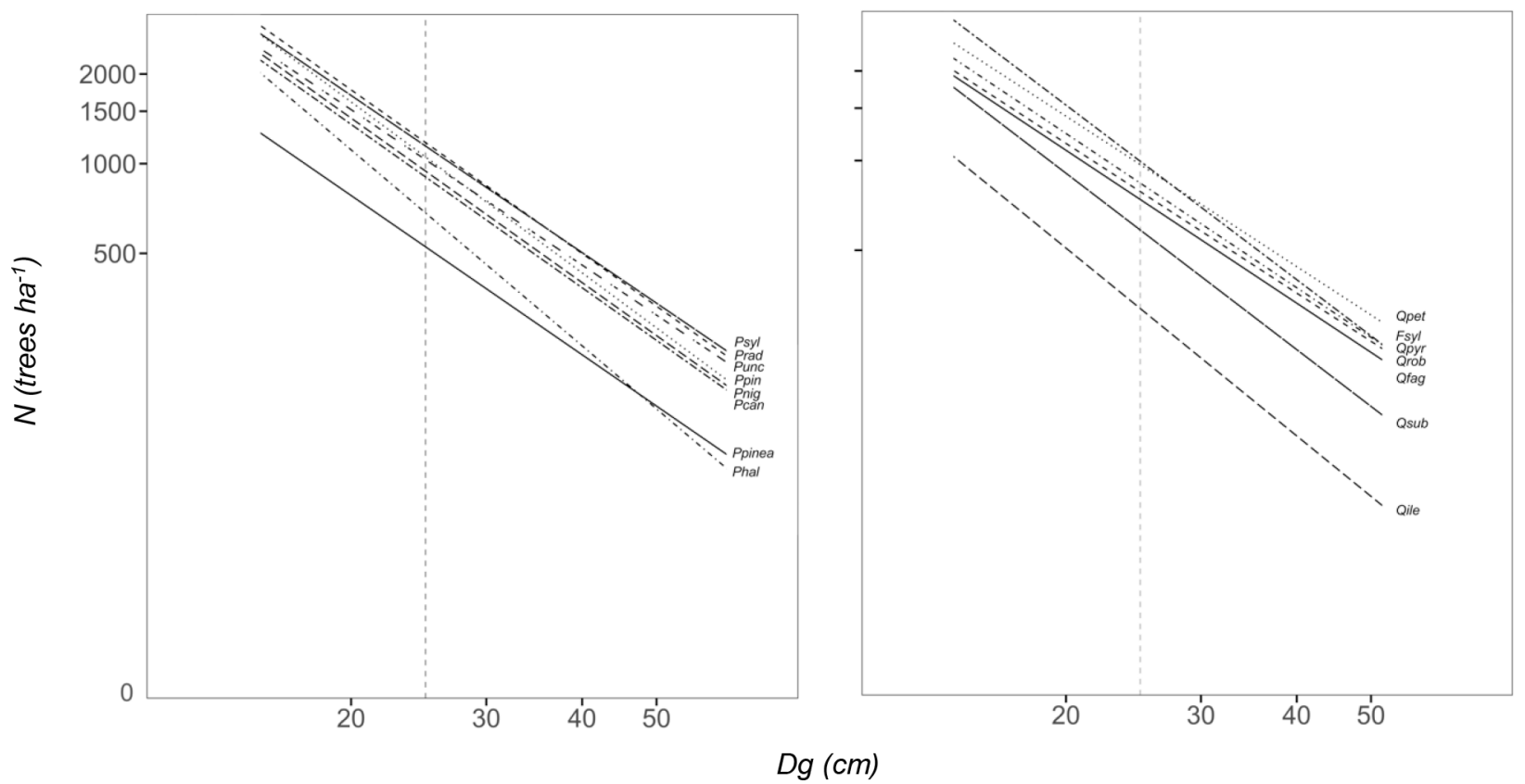

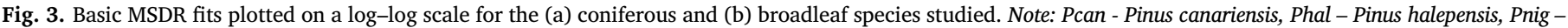

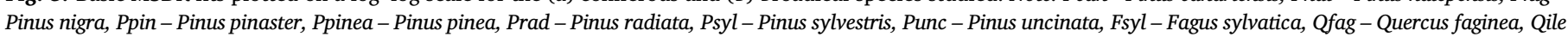
- Quercus ilex, Qpet - Quercus petraea, Qpyr - Quercus pyrenaica, Qrob - Quercus robur, Qsub - Quercus suber.

colder months of the year (Hansen and Beck, 1994). An increase in minimum temperatures could also boost the growth of individuals in mountainous areas. Smaller snowpack has been linked to higher soil water availability (Kreyling, 2010), lower mortality from root damage (Peterson and Peterson, 2001; Gedalof and Smith, 2001) and less foliar erosion from wind-blown snow (Kajimoto et al., 2002). The best climate-dependent models for Pinus halepensis indicated that seasonal maximum temperatures $\left(\mathrm{MXT}_{\mathrm{i}}\right)$, precipitation during the warmest month (PWM) and aridity (expressed as $\mathrm{M}$ ) were the key drivers affecting SDI $I_{\max }$. Small Q indexes were obtained for this species based on these models (Table 3), leading to small $\mathrm{SDI}_{\max }$ variations along its climatic range (Table 5). These results go in line with previous studies showing the high resilience and adaptation to extreme drought and heat conditions of this Mediterranean species (Baquedano and Castillo, 2007; Benito-Garzón et al., 2011; de Luis et al., 2013; Aguirre et al. 2018). Pinus uncinata and Pinus radiata also showed small variations in $\mathrm{SDI}_{\max }$ (Clim) along their distribution area according to their best climate-dependent MSDR models and Q indexes (Table 5). Particularly, the best climate-dependent model (PET3) for Pinus radiata presented an atypical behavior in which $S D I_{\max }$ (Clim) was found to decrease between percentiles 75 and 99 of this variable. This effect was also visible
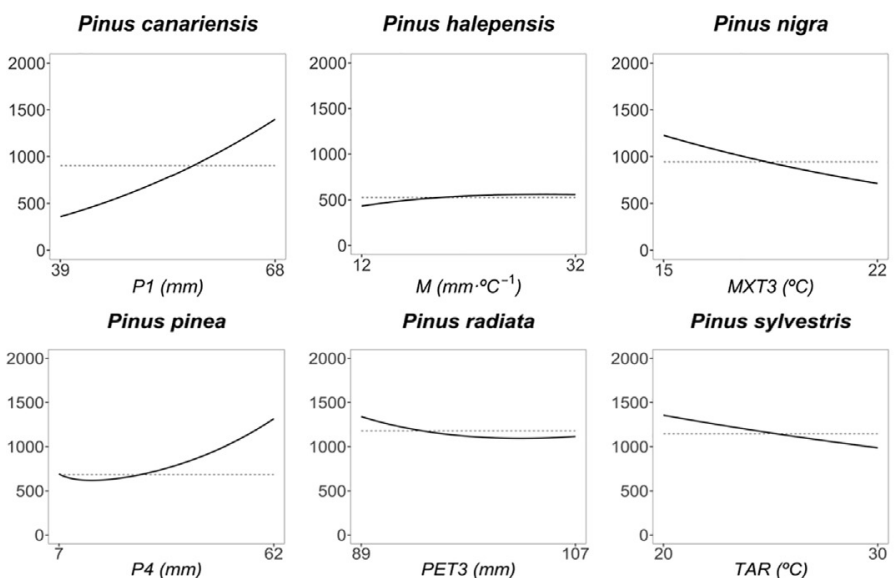

for Pinus pinea, which showed enhanced functioning at the highest values of P4. This might be explained by the link between climate and species traits, which is often too complex to adequately capture in a linear form (Reich, 2012; Craigmile and Guttorp, 2017). For this reason, further studies should test alternative model structures (i.e. multiple regression) with different combinations of climatic variables in order to better capture climate influences on MSDR and SDI max $_{\text {. Results }}$ for Pinus canariensis and Pinus pinea revealed that seasonal (Pi) and annual precipitation (P) seemed to be key variables affecting their maximum stand carrying capacity. Indeed, these species showed the highest variation in $\mathrm{SDI}_{\max }$ according to their $\mathrm{Q}$ index values (close to 0.3 ), suggesting that their maximum stand carrying capacity would be very sensitive to potential changes in precipitation regimes. In this context, climate change projections for the lower areas of the Mediterranean basin emphasize that precipitation will continue to decrease, especially during the warmest season (IPCC, 2018). Vitality (Sabaté et al., 2002; Climent et al., 2006; Sánchez-Salguero et al., 2012), growth reduction (Pasho et al., 2012; Gazol et al., 2017; NavarroCerrillo et al., 2018; Peña-Gallardo et al., 2018) and even death from xylem embolism (López et al., 2013) due to increasing extreme drought events would be expected for Mediterranean conifers and would

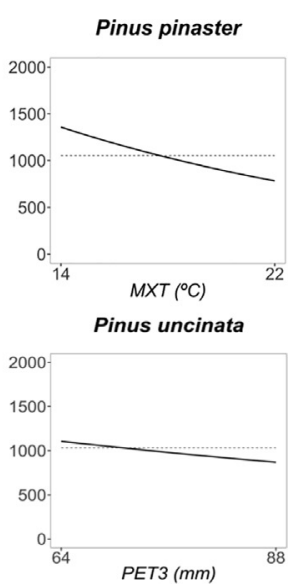

Fig. 4. Climatic influence on the maximum stand carrying capacity (expressed as $\mathrm{SDI}_{\max }$ ) for conifers. Solid line corresponds to $S D I_{\max (C l i m)}$ prediction estimates using the best climate-dependent MSDR model by species. Dashed horizontal line represents the reference value of SDI $_{\text {maxREF. Note: Temperature }}$ has been transformed toCelsius degrees $\left({ }^{\circ} \mathrm{C}\right)$. 

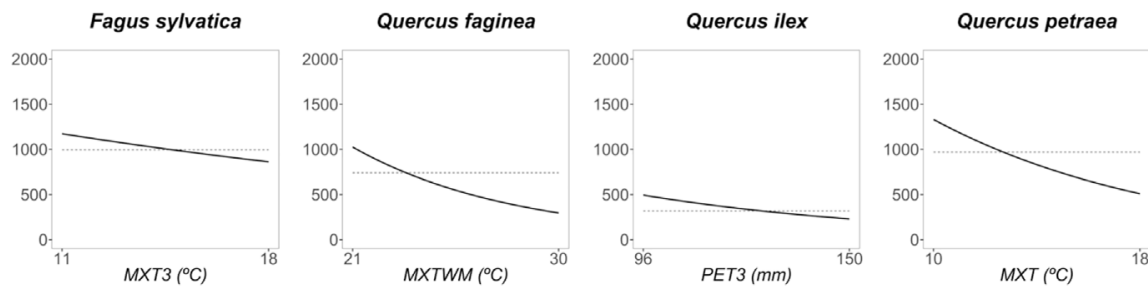

Fig. 5. Climatic influence on the maximum stand carrying capacity (expressed as $\mathrm{SDI}_{\max }$ ) of broadleaf species. Solid line corresponds to $S D I_{\max }$ (Clim) prediction estimates using the best climate-dependent MSDR model by species. Dashed horizontal line represents the reference value, SDI maxREF. Note: Temperature has been transformed to Celsius degrees $\left({ }^{\circ} \mathrm{C}\right)$.
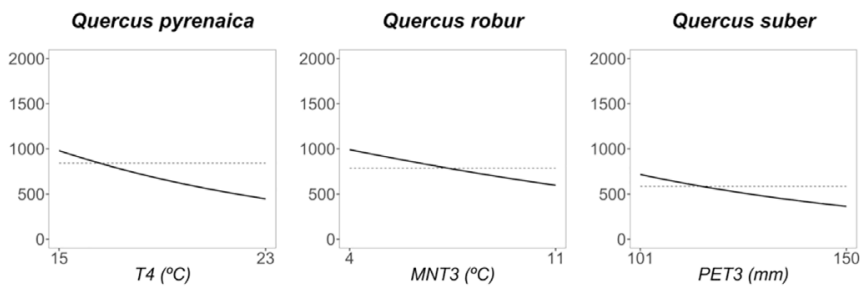

Table 6

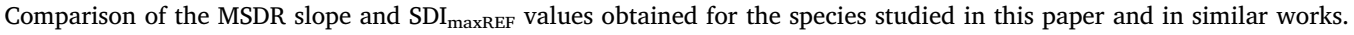

\begin{tabular}{|c|c|c|c|c|c|c|}
\hline Functional Group & Species & $\beta_{0}$ & $\mathrm{SDI}_{\operatorname{maxREF}}$ & Area & Statistical analysis & Reference \\
\hline \multirow[t]{31}{*}{ Conifers } & \multirow[t]{5}{*}{ Pinus halepensis } & -1.881 & 637 & France & SFA & Charru et al., 2012 \\
\hline & & -1.777 & 732 & Catalonia & SLR & Brunet-Navarro et al., 2016 \\
\hline & & -1.829 & 619 & Spain & QR $\left(97.5^{\text {th }}\right.$ percentile $)$ & Aguirre et al., 2018 \\
\hline & & -1.920 & 780 & France & QR & Toigo et al., 2018 \\
\hline & & -1.776 & 526 & Spain & $\mathrm{QR}\left(97.5^{\text {th }}\right.$ percentile) & This study \\
\hline & \multirow[t]{5}{*}{ Pinus nigra } & -1.653 & 881 & France & SFA & Charru et al., 2012 \\
\hline & & -1.787 & 600 & Catalonia & SLR & Brunet-Navarro et al., 2016 \\
\hline & & -1.794 & 960 & Spain & $\mathrm{QR}\left(97.5^{\text {th }}\right.$ percentile) & Aguirre et al., 2018 \\
\hline & & -1.810 & 1181 & France & QR & Toigo et al., 2018 \\
\hline & & -1.835 & 944 & Spain & $\mathrm{QR}\left(97.5^{\text {th }}\right.$ percentile) & This study \\
\hline & \multirow[t]{5}{*}{ Pinus pinaster } & -1.711 & 648 & France & SFA & Charru et al., 2012 \\
\hline & & -1.929 & 1104 & Spain & $\mathrm{QR}\left(95^{\text {th }}\right.$ percentile) & Riofrío et al. 2016 \\
\hline & & -1.983 & 1053 & Spain & $\mathrm{QR}\left(97.5^{\mathrm{th}}\right.$ percentile) & Aguirre et al., 2018 \\
\hline & & -1.860 & 807 & France & $\mathrm{QR}$ & Toigo et al., 2018 \\
\hline & & -1.906 & 1053 & Spain & QR $\left(97.5^{\text {th }}\right.$ percentile $)$ & This study \\
\hline & \multirow[t]{3}{*}{ Pinus pinea } & -1.857 & 1040 & South Spain & SLR & Montero et al., 1998 \\
\hline & & -2.122 & 702 & Spain & QR $\left(97.5^{\text {th }}\right.$ percentile $)$ & Aguirre et al., 2018 \\
\hline & & -2.186 & 683 & Spain & QR $\left(97.5^{\text {th }}\right.$ percentile) & This study \\
\hline & \multirow[t]{9}{*}{ Pinus sylvestris } & -1.750 & 1444 & Central Spain & NLR & Rio et al., 2001 \\
\hline & & -1.615 & 893 & France & SFA & Charru et al., 2012 \\
\hline & & -1.750 & 1297 & Navarra. Spain & NLR & Condés et al., 2013 \\
\hline & & -1.789 & 1144 & Spain & $\mathrm{QR}\left(95^{\text {th }}\right.$ percentile) & Riofrío et al. 2016 \\
\hline & & -1.647 & 579 & Catalonia. Spain & SLR & Brunet-Navarro et al., 2016 \\
\hline & & -1.634 & 1078 & Europe* $^{*}$ & NLQR (97.5 ${ }^{\text {th }}$ percentile) & Condés et al., 2017 \\
\hline & & -1.726 & 1154 & Spain & QR $\left(97.5^{\text {th }}\right.$ percentile) & Aguirre et al., 2018 \\
\hline & & -2.020 & 1000 & France & $\mathrm{QR}$ & Toigo et al., 2018 \\
\hline & & -1.752 & 1146 & Spain & QR $\left(97.5^{\text {th }}\right.$ percentile) & This study \\
\hline & \multirow[t]{2}{*}{ Pinus uncinata } & -1.665 & 581 & Catalonia & SLR & Brunet-Navarro et al., 2016 \\
\hline & & -1.734 & 1031 & Spain & QR (97.5 ${ }^{\text {th }}$ percentile) & This study \\
\hline & Pinus canariensis & -1.823 & 903 & Spain & QR $\left(97.5^{\text {th }}\right.$ percentile) & This study \\
\hline & Pinus radiata & -1.825 & 1178 & Spain & $\mathrm{QR}\left(97.5^{\text {th }}\right.$ percentile) & This study \\
\hline \multirow[t]{15}{*}{ Broadleaves } & \multirow[t]{5}{*}{ Fagus sylvatica } & -1.941 & 814 & France & SFA & Charru et al., 2012 \\
\hline & & -1.943 & 1184 & Europe* & NLQR (97.5 $5^{\text {th }}$ percentile) & Condés et al., 2017 \\
\hline & & -1.923 & 952 & Spain & NLQR $\left(97.5^{\text {th }}\right.$ percentile $)$ & Condés et al., 2017 \\
\hline & & -1.790 & 991 & France & $\mathrm{QR}$ & Toigo et al., 2018 \\
\hline & & -1.947 & 995 & Spain & QR $\left(97.5^{\text {th }}\right.$ percentile $)$ & This study \\
\hline & \multirow[t]{3}{*}{ Quercus petraea } & -1.911 & 685 & France & SFA & Charru et al., 2012 \\
\hline & & -2.080 & 776 & France & QR & Toigo et al., 2018 \\
\hline & & -1.678 & 969 & Spain & $\mathrm{QR}\left(97.5^{\text {th }}\right.$ percentile $)$ & This study \\
\hline & \multirow[t]{3}{*}{ Quercus robur } & -1.758 & 651 & France & SFA & Charru et al., 2012 \\
\hline & & -1.540 & 760 & France & QR & Toigo et al., 2018 \\
\hline & & -1.670 & 787 & Spain & QR $\left(97.5^{\text {th }}\right.$ percentile) & This study \\
\hline & Quercus faginea & -1.706 & 740 & Spain & $\mathrm{QR}\left(97.5^{\text {th }}\right.$ percentile) & This study \\
\hline & Quercus ilex & -2.095 & 319 & Spain & QR (97.5 $5^{\text {th }}$ percentile) & This study \\
\hline & Quercus pyrenaica & -1.720 & 840 & Spain & QR $\left(97.5^{\text {th }}\right.$ percentile) & This study \\
\hline & Quercus suber & -1.967 & 585 & Spain & $\mathrm{QR}\left(97.5^{\text {th }}\right.$ percentile) & This study \\
\hline
\end{tabular}

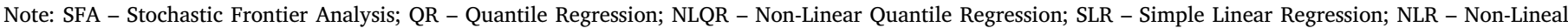
Regression

* Europe: Austria, France, Spain, Germany and Poland 
indirectly influence the maximum number of trees a stand could fully support in the future.

\subsubsection{Climatic influence on maximum stand carrying capacity for broadleaf species}

Similar to conifers, the influence of climate on MSDR was also found to be significant for all broadleaf species (Table 4). Selected climatedependent models for Fagus sylvatica showed that higher SDI max $_{\text {values }}$ were linked to wetter and milder conditions (Table 4). This result corroborates results obtained previously by Condés et al., (2017), who found a similar pattern when studying the influence of aridity on MSDR in Fagus sylvatica and Pinus sylvestris stands across a wide environmental gradient in Europe. Other studies (Friedrichs et al., 2009; Zimmermann et al., 2015) on growth dynamics have reported similar climatic impacts for this species.

For Quercus species, temperature was found to be the key driver affecting the maximum stand carrying capacity (Table 5). Based on the selected climate-dependent models by species, maximum temperatures in spring (MXT3) and summer (MXT4) influenced SDI max $_{\text {for all Quercus }}$ species except Quercus robur, which was more affected by potential changes in minimum temperatures (Table 4). Similar to the results obtained for Pinus species, higher temperatures (both maximum and

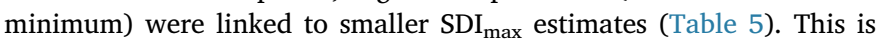
consistent with what has been found in previous studies (FernandezMarin et al., 2017; Gentilesca et al., 2017; Gil-Pelegrín et al., 2017; Kunz et al., 2018), suggesting that extreme heat and heat-induced drought conditions in the future would affect the vitality of oak stands in the Mediterranean basin. However, different responses in $\mathrm{SDI}_{\max }$ variation as effect of potential changes in temperature (Tables 4 and 5) were obtained among the Quercus species. The best climate-dependent models for Quercus faginea and Quercus pyrenaica suggest that a small increment in the temperatures of the warmest months would lead to a great decrease in the SDI max $_{\text {max }}$ of this species (Fig. 5). Indeed, Quercus faginea presented the highest Q index (0.315) among the studied oak species (Table 5) due to changes in MXTWM. Expected reductions in soil water reserves in the distribution area of this species could also foster its progressive substitution in the future by more drought-resistant species such as Quercus suber or Quercus ilex (Peñuelas et al., 2001). However, previous studies have revealed the great resilience and adaptability of Quercus faginea for surviving in extreme conditions, such as those expected in the Mediterranean Basin (Camarero et al., 2015). For this area, a pronounced warming is also predicted, giving rise to higher rates of evapotranspiration with subsequent decreases in soil water availability and increases in drought episodes (IPCC, 2018). Several authors have shown that these new conditions will drastically affect the growth and vitality of the main Mediterranean broadleaf species (Sabaté et al., 2002; Baquedano and Castillo, 2007; GeaIzquierdo et al. 2013; Gentilesca et al., 2017; Peña-Gallardo et al., 2018). In this context, different adaptation mechanisms such as leaf area reduction may be decisive for these oak species in order to reduce water loss and survive under these new conditions (Peguero-Pina et al., 2016). For Quercus petraea, maximum temperatures seemed to be also relevant climatic variables explaining potential reductions on the SDI $_{\text {max }}$ (Fig. 5) according to the best climate-dependent MSDR models obtained for this species (Table 4). Similar climatic influence was also reported by Michelot et al. (2012), who studied growth dynamics for Quercus petraea in France. However, positive impacts on growth (Kellomäki et al., 2008) and seed production (Caignard et al., 2017) could be expected in cold and mild areas, such as boreal and temperate forests, as an effect of global warming. As Spain is the western limit of Quercus petraea distribution, future climate change impacts could be more determinant for this oak species. As cited before, differences in $\mathrm{SDI}_{\max }$ for Quercus robur could well be explained by changes in seasonal minimum temperatures (Table 4). However, a small climatic impact on $\mathrm{SDI}_{\max }$ could be expected for this species linked to potential increments of minimum temperatures, according to its $\mathrm{Q}$ index (Table 5). In this study, new climate-dependent MSDR models have been fitted and new $S_{\text {SDI }}$ maxREF and $S D I_{\max }$ (Clim) for different broadleaf species have been estimated. However, further studies focused on these species are needed in order to better understand and predict potential changes in the maximum stand carrying capacity under different climate change scenarios.

\section{Conclusions}

In this study, new reference and climate-dependent MSDR models and $\mathrm{SDI}_{\max }$ values are presented for 15 coniferous and broadleaf Mediterranean tree species. For all of them, a significant climatic influence on the MSDR and the maximum stand carrying capacity was found. Maximum temperatures, especially those related to spring and summer seasons, were found to be key drivers affecting the MSDR in most of the species studied. A general trend linking smaller SDI $\mathrm{I}_{\max }$ values to warmer and drier conditions was found, suggesting that potential increments in temperatures and drought episodes would limit the maximum stand carrying capacity for these species. Climate impact on the maximum stand carrying capacity varied among species. However, according to the proposed Q index, the impact of climate on $\mathrm{SDI}_{\max }$ was found to be homogeneous among Quercus species, while conifers presented greater disparity. All the selected climate-dependent models improved the goodness of fit over the basic models, highlighting the importance of using specific climatic variables to better characterize climatic impacts on MSDR. The climate-dependent MSDR models presented in this study will allow us to more precisely estimate maximum carrying capacity, providing an advanced tool for managing monospecific and mixed stands based on current and future climatic conditions in the Mediterranean Basin. Along these lines, further studies that include more tree species and a wider range of specific climatic conditions are necessary to better understand the complex interaction between climate and the potential stocking of Mediterranean forests.

\section{CRediT authorship contribution statement}

Diego Rodríguez Prado: Conceptualization, Methodology, Formal analysis, Investigation, Data curation, Visualization, Writing - original draft, Writing - review \& editing. Roberto San Martín: Formal analysis, Writing - review \& editing. Felipe Bravo: Conceptualization, Writing review \& editing, Supervision. Celia Herrero Aza: Conceptualization, Writing - review \& editing, Supervision, Project administration.

\section{Declaration of Competing Interest}

The authors declare that they have no known competing financial interests or personal relationships that could have appeared to influence the work reported in this paper.

\section{Acknowledgements}

The authors would like to thank the Spanish Ministry of Economy and Competitiveness for funding this research through Industrial $\mathrm{PhD}$ project [grant DI-15-07722] and the Torres Quevedo programme [grant PTQ-12-05409]. The authors are also grateful to the Ministry for Ecological Transition and the WorldClim team for sharing and providing the data used in this study. Finally, the authors would also thank Andrea Blanch for revising the manuscript and providing generous linguistic advice.

\section{Appendix A. Supplementary data}

Supplementary data to this article can be found online at https:// doi.org/10.1016/j.foreco.2019.117824. 


\section{References}

Abatzoglou, J.T., Dobrowski, S.Z., Parks, S.A., Hegewisch, K.C., 2018. Terra climate, a high-resolution global dataset of monthly climate and climatic water balance from 1958-2015. Scientific Data 5, Article number: 170191.

Aguirre, A., Del Rio, M., Condés, S., 2018. Intra- and inter-specific variation of the maximum size-density relationship along an aridity gradient in Iberian pinewoods. For. Ecol. Manage. 411, 90-100.

Alberdi, I., Sandoval, V., Condés, S., Cañellas, I., Vallejo, R., 2016. El Inventario Forestal Español, una herramienta para el conocimiento, la gestión y la conservación de los ecosistemas forestales arbolados. Ecosistemas 25, 88-96.

Andrews, C., Weiskittel, A., D'Amato, A.W., Simons-Legaard, E., 2018. Variation in the maximum stand density index and its linkage to climate in mixed species forests of the North American Acadian Region. For. Ecol. Manage. 417, 90-102.

Baquedano, F.J., Castillo, F., 2007. Drought tolerance in the Mediterranean species Quercus coccifera, Quercus ilex, Pinus halepensis, and Juniperus phoenicea. Photosynthetica 45, 229.

Barbeito, I., Pardos, M., Calama, R., Canellas, I., 2008. Effect of stand structure on Stone pine (Pinus pinea L.) regeneration dynamics. Forestry 81, 617-629.

Bégin, E., Bégin, J., Bélanger, L., Rivest, L.P., Tremblay, St, 2001. Balsam fir self-thinning relationship and its constancy among different ecological regions. Can. J. For. Res. 31, 950-959.

Benito-Garzón, M., Alía, R., Robson, T.M., Zavala, M.A., 2011. Intra-specific variability and plasticity influence potential tree species distributions under climate change. Global. Ecol. Biogeogr. 20, 766-778.

Bielak, K., Dudzinska, M., Pretzsch, H., 2014. Mixed stands of Scots pine (Pinus sylvestris L.) and Norway spruce [Picea abies (L.) Karst] can be more productive than monocultures. Evidence from over 100 years of observation of long-term experiments. For. Syst. 23, 573-589.

Bi, H., Wan, G., Turvey, N.D., 2000. Estimating the self- thinning boundary line as a density-dependent stochastic biomass frontier. Ecology 81, 1477-1483.

Bi, H., 2001. The self-thinning surface. For. Sci. 47, 361-370.

Bi, H., 2004. Stochastic frontier analysis of a classic self-thinning experiment. Aust. Ecol. 29, 408-417.

Brunet-Navarro, P., Sterck, F.J., Vayreda, J., Martinez-Vilalta, J., Mohren, G.M., 2016. Self-thinning in four pine species: an evaluation of potential climate impacts. Ann. Forest Sci. 73, 1025-1034.

Caignard, T., Kremer, A., Firmat, C., Nicolas, M., Venner, S., Delzon, S., 2017. Increasing spring temperatures favor oak seed production in temperate areas. Sci. Rep. 7, 8555.

Camarero, J.J., Franquesa, M., Sangüesa-Barreda, G., 2015. Timing of drought triggers distinct growth responses in holm oak: implications to predict warming-induced forest defoliation and growth decline. Forests 6, 1576-1597.

Charru, M., Seynave, I., Morneau, F., Rivoire, M., Bontemps, J.D., 2012. Significant differences and curvilinearity in the self-thinning relationships of 11 temperate tree species assessed from forest inventory data. Ann. For. Sci. 69, 195-205.

Churchill, D.J., Larson, A.J., Dahlgreen, M.C., Franklin, J.F., Hessburg, P.F., Lutz, J.A., 2013. Restoring forest resilience: from reference spatial patterns to silvicultural prescriptions and monitoring. For. Ecol. Manage. 291, 442-457.

Climent, J., Aranda, I., Alonso, J., Pardos, J., Gil, L., 2006. Developmental constraints limit the response of Canary Island pine seedlings to combined shade and drought. For. Ecol. Manage. 231, 164-168.

Comeau, P.G., White, M., Kerr, G., Hale, S.E., 2010. Maximum density-size relationships for Sitka spruce and coastal Douglas-fir in Britain and Canada. Forestry 83, 461-468.

Condés, S., del Río, M., Sterba, H., 2013. Mixing effect on volume growth of Fagus sylvatica and Pinus sylvestris is modulated by stand density. For. Ecol. Manage. 292, 86-95.

Condés, S., Vallet, P., Bielak, K., Bravo-Oviedo, A., Coll, L., Ducey, M.J., Pach, M., Pretzsch, H., Sterba, H., Vayreda, J., 2017. Climate influences on the maximum sizedensity relationship in Scots pine (Pinus sylvestris L.) and European beech (Fagus sylvatica sylvatica L.) stands. For. Ecol. Manage. 385, 295-307.

Craigmile, P.F., Guttorp, P., 2017. Modeling and assessing climatic trends. Norwegian Computing Center eSACP:220730.

de Luis, M., Čufar, K., Di Filippo, A., Novak, K., Papadopoulos, A., Piovesan, G., Rathgeberg, C.B.K., Raventós, J., Saz, M.A., Smith, K.T., 2013. Plasticity in dendroclimatic response across the distribution range of aleppo pine (Pinus halepensis). PLoS ONE 8, e83550.

De Martonne, E., 1926. L'indice d'aridité. Bulletin de l'Association de géographes français $3,3-5$.

del Río, M., Condés, S., Pretzsch, H., 2014. Analyzing size-symmetric vs. size-asymmetric and intra-vs. inter-specific competition in beech (Fagus sylvatica L.) mixed stands. For. Ecol. Manage. 325, 90-98.

Dixon, G.E., Keyser, C.E., 2017. Northeast (NE) Variant Overview - Forest Vegetation Simulator. Internal Report. USDA, Forest Service, Forest Service Management Center, Ft. Collins, CO.

Drew, T., Flewelling, J.W., 1977. Some recent Japanese theories of yield-density relationships and their application to Monterey pine plantations. For. Sci. 23, 517-534.

Ducey, M.J., Knapp, R.A., 2010. A stand density index for complex mixed species forests in in the northeastern United States. For. Ecol. Manage. 260, 1613-1622.

Ducey, M.J., Woodall, C.W., Bravo-Oviedo, A., 2017. Climate and species functional traits influence maximum live tree stocking in the Lake States, USA. For. Ecol. Manage. 386, 51-61.

Fernandez-Marin, B., Hernández, A., Garcia-Plazaola, J.I., Esteban, R., Míguez, F., Artetxe, U., Gómez-Sagasti, M., 2017. Photoprotective strategies of mediterranean plants in relation to morphological traits and natural environmental pressure: a metaanalytical approach. Front Plant Sci. 8.
Fettig, C.J., Klepzig, K.D., Billings, R.F., Munson, A.S., Nebeker, T.E., Negron, J.F., Nowak, J.T., 2007. The effectiveness of vegetation management practices for prevention and control of bark beetle outbreaks in coniferous forests of the western and southern United States. For. Ecol. Manage. 238, 24-53.

Fick, S.E., Hijmans, R.J., 2017. Worldclim 2: new 1-km spatial resolution climate surfaces for global land areas. Int. J. Climatol. 37, 4302-4315.

Fowler, C.W., 1981. Density dependence as related to life history strategy. Ecol. Soc. Am. 62, 602-610.

Friedrichs, D.A., Trouet, V., Büntgen, U., Frank, D.C., Esper, J., Neuwirth, B., Löffler, J., 2009. Species-specific climate sensitivity of tree growth in Central-West Germany. Trees 23, 729-739.

Gazol, A., Ribas, M., Gutiérrez, E., Camarero, J.J., 2017. Aleppo pine forests from across Spain show drought-induced growth decline and partial recovery. Agric. For. Meteorol. 232, 186-194.

Gea-Izquierdo, G., Fernández De Uña, L., Cañellas, I., 2013. Growth projections reveal local vulnerability of Mediterranean oaks with rising temperatures. For. Ecol. Manage. 305, 282-293.

Gedalof, Z., Smith, D.J., 2001. Dendroclimatic response of mountain hemlock (Tsuga mertensiana) in Pacific North America. Can. J. For. Res. 31, 322-332.

Gentilesca, T., Camarero, J.J., Colangelo, M., Nolè, A., Ripullone, F., 2017. Drought-induced oak decline in the western Mediterranean region: an overview on current evidences, mechanisms and management options to improve forest resilience. iFor. Biogeosci. For. 10, 796-806.

Gil-Pelegrín, E., Saz, M.Á., Cuadrat, J.M., Peguero-Pina, J.J., Sancho-Knapik, D., 2017. Oaks under Mediterranean-type climates: functional response to summer aridity. In: Gil-Pelegrín E., Peguero-Pina J., Sancho-Knapik D. (eds) Oaks physiological ecology. Exploring the functional diversity of genus Quercus L. Tree Physiology 7. Springer, Cham.

Hann, D.W., 2014. Modeling of the maximum size-density line and its trajectory line for tree species: Observations and opinions. For. Biometrics Res. Pap. 5. Oregon State University, College of Forestry. Corvallis, OR. pp. 33.

Hansen, J., Beck, E., 1994. Seasonal changes in the utilization and turnover of assimilation products in 8-year-old Scots pine (Pinus sylvestris L.) trees. Trees Struct. Func. 8, $172-182$.

Herrero, C., Bravo, F., 2012. Can we get an operational indicator of forest carbon sequestration? A case study from two forest regions in Spain. Ecol. Indicators. 17, $120-126$.

Hutchings, M.J., Budd, C.S., 1981. Plant competition and its course through time. BioScience 3, 640-645.

IPCC, 2018. Global Warming of $1.5^{\circ} \mathrm{C}$. An IPCC Special Report on the impacts of global warming of $1.5^{\circ} \mathrm{C}$ above pre-industrial levels and related global greenhouse gas emission pathways, in the context of strengthening the global response to the threat of climate change, sustainable development, and efforts to eradicate poverty [Masson-Delmotte, V., P. Zhai, H.-O. Pörtner, D. Roberts, J. Skea, P.R. Shukla, A. Pirani, Moufouma-Okia, C. Péan, R. Pidcock, S. Connors, J.B.R. Matthews, Y. Chen, X. Zhou, M.I. Gomis, E. Lonnoy, Maycock, M. Tignor, and T. Waterfield (eds.)]. World Meteorological Organization, Geneva, Switzerland, $32 \mathrm{pp}$.

Jack, S.B., Long, J.N., 1996. Linkages between silviculture and ecology: an analysis of density management diagrams. For. Ecol. Manage. 86, 205-220.

Kajimoto, T., Seki, T., Ikeda, S., Daimaru, H., Okamoto, T., Onodera, H., 2002. Effects of snowfall fluctuation on tree growth and establishment of subalpine Abies mariesii near upper forest-limit of Mt. Yumori, northern Japan. Arct. Antarct. Alp. Res. 34, 191-200.

Kellomäki, S., Peltola, H., Nuutinen, T., Korhonen, K.T., Strandman, H., 2008. Sensitivity of managed boreal forests in Finland to climate change, with implications for adaptive management. Philos. Trans. R. Soc. London, Ser. B Biol. Sci. 363, 2341-2351.

Kimsey, M.J., Shaw, T.M., Coleman, M.D., 2019. Site sensitive maximum stand density index models for mixed conifer stands across the Inland Northwest, USA. For. Ecol. Manage. 433, 396-404.

Koenker, R., Bassett, G., 1978. Regression quantiles. Econometrica 46, 33-50.

Koenker, R., Machado, J.A., 1999. Goodness of fit and related inference processes for quantile regression. J. Am. Statist. Assoc. 94, 1296-1310.

Koenker, R., 2015. quantreg: Quantile Regression. R package version 5.05. R Foundation for Statistical Computing: Vienna. Available at: http://CRAN.R-project.org/ package $=$ quantreg.

Kreyling, J., 2010. Winter climate change: a critical factor for temperate vegetation performance. Ecology 91, 1939-1948.

Kunz, J., Räder, A., Bauhus, J., 2018. Minor European broadleaved tree species are more drought-tolerant than Fagus sylvatica but not more tolerant than Quercus petraea. For. Ecol. Manage. 414, 15-27.

Kurz-Besson, C.B., Lousada, J.L., Gaspar, M.J., Correia, I.E., David, T.S., Soares, P.M., Cardoso, R.M., Russo, A., Varino, F., Mériaux, C., Trigo, R.M., Gouveia, C.M., 2016. Effects of recent minimum temperature and water deficit increases on Pinus pinaster radial growth and wood density in Southern Portugal. Front. Plant Sci. 7, 1170.

Kweon, D., Comeau, P.G., 2017. Effects of climate on maximum size-density relationships in Western Canadian trembling aspen stands. For. Ecol. Manage. 406, 281-289.

Long, J.N., Shaw, J.D., 2005. A density management diagram for even-aged ponderosa pine stands. West. J. Appl. For. 20, 205-215.

López, R., López de Heredia, U., Collada, C., Cano, F.J., Emerson, B.C., Cochard, H., Gil, L., 2013. Vulnerability to cavitation, hydraulic efficiency, growth and survival in an insular pine (Pinus canariensis). Ann Bot. 111, 1167-1179.

Makela, A., Landsberg, J., Ek, A.R., Burk, T.E., Ter-Mikaelian, M., Agren, G.I., Oliver, C.D., Puttonen, P., 2000. Process-based models for forest ecosystem management: current state of the art and challenges for practical implementation. Tree Physiol. 20, 289-298.

Michelot, A., Simard, S., Rathgeber, C., Dufrêne, E., Damesin, C., 2012. Comparing the 
intra-annual wood formation of three European species (Fagus sylvatica, Quercus petraea and Pinus sylvestris) as related to leaf phenology and non-structural carbohydrate dynamics. Tree Physiol. 32, 1033-1045.

Montero, G., Candela, J., Gutiérrez, M., Pavón, J., Ortega, C., García, C., Cañellas, I., 1998. Manual de claras para repoblaciones de Pinus pinea L. Editado por EGMASA y Junta de Andalucía.

Moore, M.M., Deiter, D.A., 1992. Stand density index as a predictor of forage production in northern Arizona ponderosa pine forests. J. Range Manage. 45, 267-271.

Morris, C.E., 2003. How does fertility of the substrate affect intraspecific competition? Evidence and synthesis from self-thinning. Ecol. Res. 18, 287-305.

Navarro-Cerrillo, R.M., Rodríguez-Vallejo, C., Silveiro, E., Hortal, A.A., PalaciosRodríguez, G., Duque-Lazo, J., Camarero, J.J., 2018. Cumulative drought stress leads to a loss of growth resilience and explains higher mortality in planted than in naturally regenerated Pinus pinaster stands. Forests 9, 358.

Niinemets, Ü., Valladares, F., 2006. Tolerance to shade, drought, and waterlogging of temperate northern hemisphere trees and shrubs. Ecol. Monogr. 76, 521-547.

Panagos, P., Borrelli, P., Meusburger, K., Yu, B., Klik, A., Lim, K., Yang, J., Ni, J., Miao, C., Chattopadhyay, N., Sadeghi, S.H., Hazbavi, Z., Zabihi, M., Larionov, G., Krasnov, S., Gorobets, A., Levi, Y., Erpul, G., Birkel, C., Ballabio, C. 2017. Global rainfall erosivity assessment based on high-temporal resolution rainfall records. Sci. Rep. 7, Article Number 4175.

Pasho, E., Camarero, J.J., Vicente-Serrano, S.M., 2012. Climatic impacts and drought control of radial growth and seasonal wood formation in Pinus halepensis. Trees 26, 1875-1886.

Peguero-Pina, J.J., Sisó, S., Sancho-Knapik, D., Díaz-Espejo, A., Flexas, J., Galmés, J., GilPelegrín, E., 2016. Leaf morphological and physiological adaptations of a deciduous oak (Quercus faginea Lam.) to the Mediterranean climate: a comparison with a closely related temperate species (Quercus robur L.). Tree Physiol. 36, 287-299.

Peña-Gallardo, M., Vicente-Serrano, S.M., Camarero, J.J., Gazol, A., Sánchez-Salguero, R., Domínguez-Castro, F., El-Kenawy, A.M., Beguería, S.; Gutiérrez, E., de-Luis,M. Sangüesa-Barreda, G., Novak, K.; Rozas, V., Tíscar, P.A., Linares, J.C., Martínez-delCastillo, E., Ribas-Matamoros, M., García-González, I; Silla, F., Camisón, A., Génova, M., Olano, J.M., Longares, L.A., Hevia, A., Galván, D., 2018. Drought sensitiveness on forest growth in peninsular Spain and the Balearic Islands. Forests 2018, 9, 524.

Peñuelas, J., Lloret, F., Montoya, R., 2001. Severe drought effects on Mediterranean woody flora of Spain. For. Sci. 47, 214-218.

Peterson, D.W., Peterson, D.L., 2001. Mountain hemlock growth responds to climatic variability at annual and decadal time scales. Ecology 82, 3330-3345.

Poggio, L., Simonetti, E., Gimona, A., 2018. Enhancing the WorldClim data set for national and regional applications. Sci. Total Environ. 625, 1628-1643.

Pretzsch, H., Biber, P., 2005. A re-evaluation of Reineke's rule and stand density index. For. Sci. 51, 304-320.

Pretzsch, H., Biber, P., 2016. Tree species mixing can increase maximum stand density. Can. J. For. Res. 46, 1179-1193.

R Core Team, 2018. R: A language and environment for statistical computing. R Foundation for Statistical Computing, Vienna, Austria. https://www.R-project.org/.

Rathgeber, C.B.K., Misson, L., Nicault, A., Guiot, J., 2005. Bioclimatic model of tree radial growth: application to the French Mediterranean Aleppo pine forests. Trees 19, $162-176$.

Ratwosky, D.A., 1983. Nonlinear regression modeling. A unified practical approach. Marcel Dekker Inc., New York.

Reich, B.J., 2012. Spatiotemporal quantile regression for detecting distributional changes in environmental processes. J. R. Stat. Soc. Ser. C (Appl. Stat.) 61, 535-553.
Reineke, L.H., 1933. Perfecting a stand-density index for even-aged forests. J. Agric. Res. 46, 627-638.

Reyes-Hernandez, V., Comeau, P.G., Bokalo, M., 2013. Static and dynamic maximum sizedensity relationships for mixed trembling aspen and white spruce stands in western Canada. For. Ecol. Manage. 289, 300-311.

Rio, M., Montero, G., Bravo, F., 2001. Analysis of diameter-density relationships and selfthinning in non-thinned even-aged Scots pine stands. For. Ecol. Manage. 142, 79-87.

Riofrío, J., del Río, M., Bravo, F., 2016. Mixing effects on growth efficiency in mixed pine forests. Forestry 90, 381-392.

Sabaté, S., Gracia, C.A., Sánchez, A., 2002. Likely effects of climate change on growth of Quercus ilex, Pinus halepensis, Pinus pinaster, Pinus sylvestris and Fagus sylvatica forests in the Mediterranean region. For. Ecol. Manage. 162, 23-37.

Sánchez-Salguero, R., Navarro-Cerrillo, R.M., Swetnam, T.W., Zavala, M.A., 2012. Is drought the main decline factor at the rear edge of Europe? The case of southern Iberian pine plantations. For. Ecol. Manage. 271, 158-169.

Toigo, M., Perot, T., Courbaud, B., Castagneyrol, B., Gégout, J.C., Longuetaud, F., Jactel, H., Vallet, P., 2018. Difference in shade tolerance drives the mixture effect on oak productivity. J. Ecol. 106, 1073-1082.

Trabucco, A., Zomer, R.J., 2009. Global aridity index (global-aridity) and global potential evapo-transpiration (global-PET) geospatial database. CGIAR Consortium for Spatial Information. Published online, available from the CGIAR-CSI GeoPortal at: http:// www.csi.cgiar.org.

Valbuena, P., Del Peso, C., Bravo, F., 2008. Stand density Management diagrams for two mediterranean pine species in Eastern Spain. Forest Syst. 17, 97-104.

Vieira, J., Rossi, S., Campelo, F., Freitas, H., Nabais, C., 2014. Xylogenesis of Pinus pinaster under a Mediterranean climate. Ann. For. Sci. 71, 71-80.

Vospernik, S., Sterba, H., 2015. Do competition-density rule and self-thinning rule agree? Ann. For. Sci. 72, 379-390.

Weiskittel, A., Gould, P., Temesgen, H., 2009. Sources of variation in the self-thinning boundary line for three species with varying levels of shade tolerance. For. Sci. 55, 84-93.

Weller, D.E., 1987. A reevaluation of the $-3 / 2 \%$ power rule of plant self-thinning. Ecol. Monogr. 57, 23-43.

Woodall, C.W., D'Amato, A.W., Bradford, J.B., Finley, A.O., 2011. Effects of stand and inter-specific stocking on maximizing standing tree carbon stocks in the Eastern United States. For. Sci. 57, 365-378.

Woodall, C.W., Miles, P.D., Vissage, J.S., 2005. Determining maximum stand density index in mixed species stands for strategic-scale stocking assessments. For. Ecol. Manage. 216, 367-377.

Yang, Y., Titus, S.J., 2002. Maximum size-density relationships for constraining individual tree mortality functions. For. Ecol. Manage. 168, 259-273.

Yoda, K., Kira, T., Ogawa, H., Hozumi, K., 1963. Self-thinning in overcrowded pure stands under cultivated and natural conditions (Intraspecific competition among higher plants XI). J. Biol. 14, 107-129.

Zeide, B., 1987. Analysis of the 3/2 power law of self-thinning. For. Sci. 33, 517-537.

Zeide, B., 2005. How to measure stand density. Trees - Struct. Funct. 19, 1-14.

Zhang, L.J., Bi, H.Q., Gove, J.H., Heath, L.S., 2005. A comparison of alternative methods for estimating the self-thinning boundary line. Can. J. For. Res. 35, 1507-1514.

Zhang, J., Oliver, W.W., Powers, R.F., 2013. Reevaluating the self-thinning boundary line for ponderosa pine (Pinus ponderosa) forests. Can. J. For. Res. 43, 963-971.

Zimmermann, J., Hauck, M., Dulamsuren, C., Leuschner, C.J., 2015. Climate warmingrelated growth decline affects Fagus Sylvatica, but not other broad-leaved tree species in central European mixed forests. Ecosystems 18, 560-572. 